\title{
BUSINESS ANGELS RESEARCH IN ENTREPRENEURIAL FINANCE: A LITERATURE REVIEW AND A RESEARCH AGENDA
}

\author{
Francesca Tenca* and Annalisa Croce \\ Politecnico di Milano Dipartimento di Ingegneria Gestionale \\ Elisa Ughetto \\ Politecnico di Torino and BRICK \\ Collegio Carlo Alberto
}

\begin{abstract}
Since the seminal works of Wetzel, research on business angels (BAs) has emerged as a new and promising research field. This review analyses the current knowledge on BAs, identifying the main contents and outcomes. We also provide a bibliometric analysis to illustrate the evolution of the research field, the level of dispersion of the scientific community, the main outlets for publication and the different methodological approaches adopted. Through the analysis of backward and forward citations, we depict the current knowledge base on which BA research is grounded and whether it has any impact on other research fields.
\end{abstract}

Keywords. Business angels; Entrepreneurial finance; Review

\section{Introduction}

Since the seminal works of Wetzel (1981a,b, 1983), research on business angels (henceforth, BAs) has emerged as a new and promising research field. BAs are high wealthy individuals, usually former entrepreneurs or professionals, who invest their own money in promising start-ups in which they have no direct connection, in exchange for ownership equity, acting alone or through semiformal networks. They provide seed or growth capital, as well as advice and hands-on assistance (Wetzel, 1983; Mason and Harrison, 2000; Lindsay, 2004).

BAs' research lies at the intersection of economics, finance and business management. The interest in BAs has grown rapidly in consideration of the important role they play in facilitating the growth of new ventures. First, BAs are a crucial component of the entrepreneurial ecosystem: they contribute to bring innovation to the economy, investing at the earliest stages of ventures' lifecycle, long before a typical institutional investor would take interest. Moreover, BAs usually add substantial value beyond cash, becoming active members in the management of the company and providing significant advice. Indeed, BAs' capital is also called 'smart money' because of the value they add through their experience, counselling, and networking, and because they facilitate the raise of additional funding at a later stage (Aernoudt, 2005).

*Corresponding author contact email: annalisa.croce@ polimi.it; Tel: +390223992743. 
While it is not easy to quantify the size of the angel market accurately, available figures report that the USA (European) BA market is approximately the same size of the USA (European) venture capital (VC) market, totalling $\$ 17.7$ billion ( $\$ 5.6$ billion) and $\$ 18.3$ billion ( $\$ 5.3$ billion), respectively (Organisation for Economic Co-operation and Development, OECD, 2011).

Although scholarly interest in BAs has grown in the last decade and some literature reviews exist, they are limited both in their scope (i.e. focusing on specific aspects of BA financing) and adopted methodology. ${ }^{1}$ Hence, the cumulative knowledge on BAs lacks a more integrated view on the results achieved so far.

The objective of this review paper is twofold. First, we provide an extensive review of the literature, mapping prior research in the area by including all the main streams of research and a large spectrum of journals. In doing so, we assess the success and future viability of the research field and identify avenues for future research. To date, current research has used a limited number of theoretical perspectives, adopted few rigorous methodologies and has insufficiently accounted for the heterogeneity of BAs within groups/networks, in different national, cultural and institutional contexts, in their relationship with other investors (i.e. VC) and in their approaches to the investment process. In general, this review aims to structure the current knowledge on BAs and to bring some systematization to an area that is poorly organized, in order to identify the main contents and outcomes. Second, we provide a bibliometric analysis to illustrate the evolution of the research field in the last decades, the level of dispersion of the scientific community, the main outlets for publication, the methodological approaches and challenges in doing BAs' research. In particular, through the analysis of backward and forward citations, we depict the current state of knowledge on which BAs' research is grounded and we examine whether it has any impact on other research fields.

We use the Scopus database to run our searches of the reviewed articles. The use of Scopus database allows to follow a bibliometric perspective that adds an important original contribution with respect to other different narratives and to other literature reviews on the topic. In fact, the bibliometric analysis highlights the increasing importance and legitimacy of BAs' research in a formal and objective way, directing scholars, who intend to perform impact research in the field, towards the hottest topics. However, it is important to clarify that the use of Scopus to compute the bibliometric metrics inevitably leads to overlook a number of papers (see next section) that are not included in the database. ${ }^{2}$

Using Scopus, we identify 148 articles published in entrepreneurship, finance, and economics journals and we categorize the prevailing themes addressed by the community of scholars studying BAs into three thematic areas (BA characteristics, BA market and BA investment process) and eleven research lines. We discuss prior works in these three research areas, highlighting the research gaps, as well as the key challenges, and drawing insights that can help to advance BAs' research.

The paper is organized as follows. First we describe the methodology used to select and classify the articles reviewed. Then, we summarize the findings of the prior literature, along the different thematic areas and research lines identified. This is followed by the results of the bibliometric analysis. Finally, we conclude providing some directions for future research.

\section{Methodology}

This section describes the steps we followed to select and analyse the articles included in our literature review on BA research.

The first stage of the process was setting the inclusion criteria and the strategy for the search and selection of the reviewed studies. We selected articles written in English and published in peer reviewed journals between 1981 (when the first known article on BAs was published) and 2015. Books, book chapters, conference proceedings and unpublished works were excluded. ${ }^{3}$

The primary source for selecting the articles was the online database Scopus, which was used in other literature reviews in entrepreneurship (Ghio et al., 2015). We searched within the title, the abstract, and the keywords the following search strings: 'business angel(s)', 'angel investing', 'angel financing', 'informal 
risk capital' and 'informal investor(s)', in addition to restricting the search to the Economy and Business research areas of the database. The structured searching process retrieved over 350 papers. ${ }^{4}$ We manually checked all the abstracts to exclude those papers that did not clearly refer to BAs, leading to a reduced sample of 148 papers. ${ }^{5}$

We initially recorded for each article the following information: (1) name(s) of the author(s), (2) year of publication, (3) journal, (4) unit of analysis (i.e. individual BA, angel group, angel network, BA market), (5) country, (7) research question(s), (9) data, (10) methodology and (11) key findings. Once the content of the articles was systematically organized, we conducted a first level thematic analysis by coding the abstracts through an inductive approach, that is deriving a set of thematic areas from the data itself (Pittaway et al., 2004; Thorpe et al., 2005). The thematic areas represent the fundamental concepts on which an article's research questions, theoretical basis, models and/or hypotheses are based (Thorpe et al., 2005). The thematic areas were, then, refined and more detailed research lines were identified.

We identified three main thematic areas: BA characteristics, BA market and BA investment process. The research stream on BA characteristics is the first to emerge in the BA literature. It includes the majority of the seminal and early papers that are mainly descriptive in nature. These studies focus on the definition of angel investors and categorize BAs into typologies, based upon their personal characteristics and investing preferences. They also compare individual BAs' profiles across countries, address gender issues and describe the roles played by angel networks and angel groups. We found 37 publications in this area $(25 \%)$, that we further categorized into four research lines: (1) profiles and types, (2) international differences in profiles, (3) gender and (4) networks and groups.

The second thematic area is BA market, comprising 34 articles (23\%). These articles provide estimates of the size of the BA market, examine the dynamics of demand and supply in the informal risk capital market, analyse the role played by BAs in filling regional equity gaps and in stimulating regional economic development and examine the governmental policies implemented or needed to stimulate BA investing activity at both regional and country levels. This thematic area includes three research lines: (1) demand and supply of angel capital, (2) effectiveness of angel financing on regional growth and (3) policies to foster the informal risk capital market.

The last thematic area, which we labelled BA investment process, is the most extensive one, including 77 papers $(52 \%)$. These studies aim to understand the underlying dynamics of the BAs' investment process. We distinguished four research lines: (1) selection, evaluation and funding, (2) post-investment, (3) impact on investees' performances and (4) overview of the entire investment process. Table 1 illustrates the distribution of the reviewed articles by thematic area and research line.

Figure 1 shows the 148 reviewed articles spanning the period 1981-2015, by thematic area. After the two seminal articles published by Wetzel in 1981 and 1983, the overall distribution of publications shows that BA research has attracted a certain scholarly interest since 2003 and then more consistently beginning from 2007 (with the exception of 2009). We can see that recently, especially beginning from 2011, the growth in the number of publications is mainly due to a shift in the papers' thematic area, from an early emphasis on BA characteristics towards the understanding of the mechanisms underlying the BA investment process.

\section{Main Contributions of BA Research}

In this section, we present the main contributions of BA research. We organize the discussion of the literature results along the thematic areas and research lines identified in the methodology section.

\subsection{BA Characteristics}

The first thematic area that emerged in BA research is concerned with individual BAs' characteristics. This thematic area accounts for 37 papers describing the profile of BAs in terms of their business background, 
Table 1. Distribution of the Reviewed Articles by Thematic Area and Research Line.

\begin{tabular}{|c|c|c|c|}
\hline Thematic area & Research line & Description & $\begin{array}{l}\text { Year of first } \\
\text { publication }\end{array}$ \\
\hline \multirow[t]{4}{*}{$\begin{array}{l}\text { BA characteristics } \\
\text { (37 articles, } \\
25 \%)\end{array}$} & $\begin{array}{l}\text { Profiles and types ( } 22 \\
\text { articles) }\end{array}$ & $\begin{array}{l}\text { Studies that examine BAs' typical } \\
\text { profile and categorize BAs into } \\
\text { different typologies }\end{array}$ & 1981 \\
\hline & $\begin{array}{l}\text { International } \\
\text { differences in } \\
\text { profiles (8 articles) }\end{array}$ & $\begin{array}{l}\text { Studies that compare BAs' profiles } \\
\text { across different countries }\end{array}$ & 1992 \\
\hline & Gender (5 articles) & Studies focusing on gender issues & 2006 \\
\hline & $\begin{array}{l}\text { Networks and groups } \\
\text { ( } 2 \text { articles) }\end{array}$ & $\begin{array}{l}\text { Studies describing the roles played by } \\
\text { BA networks and groups }\end{array}$ & 2010 \\
\hline \multirow[t]{3}{*}{$\begin{array}{l}\text { BA market (34 } \\
\text { articles, 23\%) }\end{array}$} & $\begin{array}{l}\text { Demand and supply of } \\
\text { angel capital ( } 15 \\
\text { articles) }\end{array}$ & $\begin{array}{l}\text { Studies that provide estimates of the } \\
\text { size of the BA market and that } \\
\text { examine the dynamics of demand } \\
\text { and supply in the market }\end{array}$ & 1987 \\
\hline & $\begin{array}{l}\text { Effectiveness of angel } \\
\text { financing on } \\
\text { regional growth ( } 6 \\
\text { articles) }\end{array}$ & $\begin{array}{l}\text { Studies that examine the role played by } \\
\text { BAs in filling regional equity gaps } \\
\text { and in stimulating regional economic } \\
\text { development }\end{array}$ & 1991 \\
\hline & $\begin{array}{l}\text { Policies to foster the } \\
\text { informal risk capital } \\
\text { market (13 articles) }\end{array}$ & $\begin{array}{l}\text { Studies that examine the governmental } \\
\text { policies implemented or needed to } \\
\text { stimulate BAs' investing activity at } \\
\text { both regional and country levels }\end{array}$ & 1992 \\
\hline \multirow[t]{4}{*}{$\begin{array}{l}\text { BA investment } \\
\text { process }(77 \\
\text { articles, } 52 \%)\end{array}$} & $\begin{array}{l}\text { Selection, evaluation } \\
\text { and funding ( } 36 \\
\text { articles) }\end{array}$ & $\begin{array}{l}\text { Studies that examine BAs' } \\
\text { decision-making criteria in the } \\
\text { screening, evaluation and funding } \\
\text { decision of investment proposals }\end{array}$ & 1988 \\
\hline & $\begin{array}{l}\text { Post-investment (10 } \\
\text { articles) }\end{array}$ & $\begin{array}{l}\text { Studies that examine BAs' } \\
\text { post-investment involvement in the } \\
\text { invested firms }\end{array}$ & 1996 \\
\hline & $\begin{array}{l}\text { Impact on investees' } \\
\text { performances }(20 \\
\text { articles) }\end{array}$ & $\begin{array}{l}\text { Studies that evaluate the impact of BA } \\
\text { financing on invested firms' } \\
\text { performances }\end{array}$ & 2002 \\
\hline & $\begin{array}{l}\text { Overview of the entire } \\
\text { investment process } \\
\text { (11 articles) }\end{array}$ & $\begin{array}{l}\text { Studies that examine the different } \\
\text { phases of the entire BA investment } \\
\text { process }\end{array}$ & 2003 \\
\hline
\end{tabular}

experience and education, motivations to invest and investing criteria, behaviour and investment activity.

Within this thematic area, we identified four research lines. Profiles and types is the most extensive research line, accounting for 22 papers. A first set of papers provides a description of BAs' profiles in terms of portfolio size, investment motivations and preferences, syndication strategies (Wetzel, 1983; Aram, 1989; Moen et al., 2008; Lahti, 2011a), psychological traits (Duxbury et al., 1996), business background and experience, investing criteria and outcomes (Landström, 1992; Paul et al., 2003), factors differentiating professional BAs from non-investors or family and friends capital providers (Maula et al., 


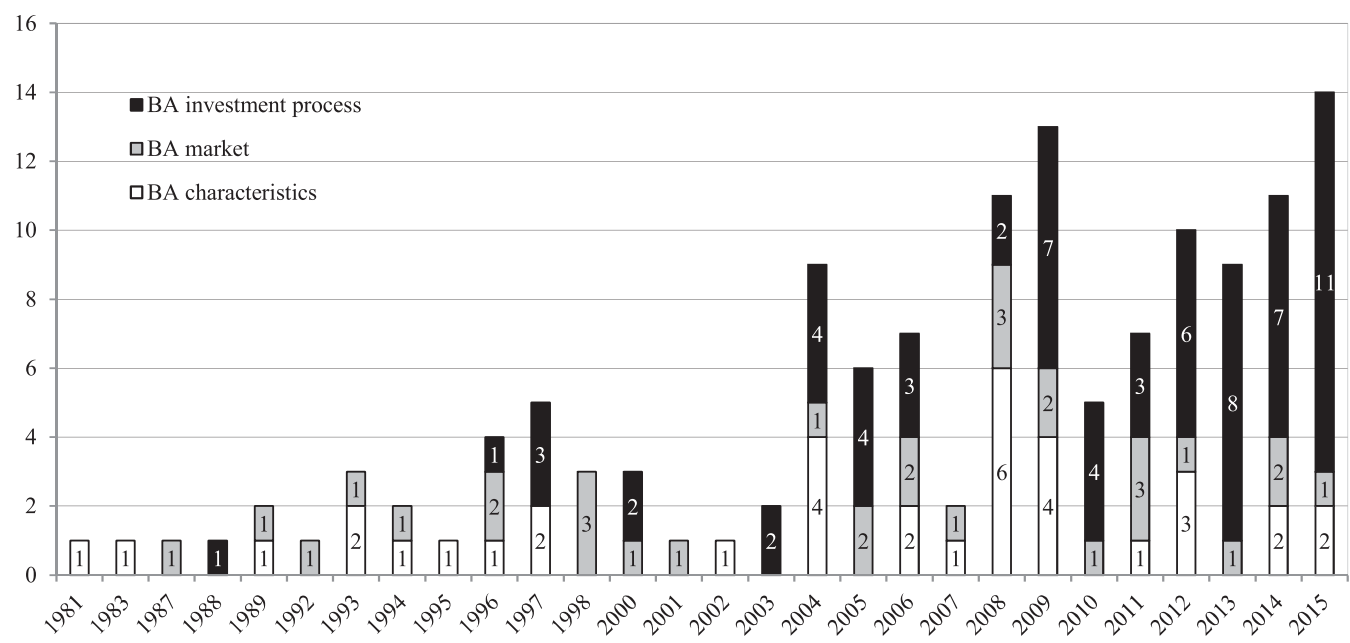

Figure 1. Number of Articles Published per Year, by Thematic Area.

2005; Wong and Ho, 2007; Li et al., 2014a,b). Typical BAs are portrayed as male, high net worth, middleage individuals, with considerable entrepreneurial experience and networks, who prefer early stage investments, in high-tech companies, located in their proximity (Wetzel, 1983; Aram, 1989; Maula et al. 2005; Wong and Ho, 2007; Riding, 2008). They are usually patient investors, also driven by non-financial motivations, and willing to be involved in the post-investment management of their companies (Wetzel, 1983; Duxbury et al., 1996). However, these studies have also recognised that BAs can be heterogeneous in their characteristics and investment behaviours. Differences among BAs relate to their demographical characteristics, income and education (Szerb et al., 2007a,b), their motivations and willingness to invest (Freear et al., 1994; Sullivan and Miller, 1996; Robinson and Cottrell, 2007; Szerb et al., 2007a,b), their investing experience and competences (Sørheim and Landström, 2001; Avdeitchikova, 2008) and their investment practices and post-investment involvement (Lathi, 2011b; Landström, 1992). Some recent papers also address the possibility that BAs have dynamic investment patterns, over time or in different contexts (Robinson and Cottrell, 2007; Avdeitchikova, 2008; Avdeitchikova et al., 2008; Lathi, 2011b). A few additional studies focus on particular typologies of BAs, defined as 'technology angels' (Erikson and Sørheim, 2005) or 'founding angels' ${ }^{6}$ (Festel and De Cleyn, 2013a).

The second research line International differences in profiles counts eight papers, in which BA characteristics and behaviours are compared among different countries and institutional settings. The comparison is often made between the more developed USA financial market and the European one (Harrison and Mason, 1992; Landström, 1993; Wilson, 1995; Brettel, 2003), among different European countries (Bygrave et al., 2003; Stedler and Peters, 2003; Ding et al., 2015) and more recently, between emerging economies and established ones (Li et al., 2014a,b; Scheela et al., 2015). ${ }^{7}$ Evidence shows that in comparison to the United States, European BAs invest lower amounts, they are less patient and less risk-adverse investors, while they usually experience higher investment returns (Wilson, 1995; Brettel, 2003). Instead, concerning the differences between emerging economies and developed ones, it has been found that BAs in China, for example, tend to make larger localized investments (by syndication) than BAs in the United States and Europe. They are, also, less patient and less involved in their invested companies in the post-investment phase (Li et al., 2014a,b).

More in general, a significant gap between BAs' research in developed versus emerging economies has emerged. Most of the current knowledge is summarized in a recent review by Scheela et al. (2015), ${ }^{8}$ 
focusing on VCs' and BAs' practices in emerging economies of Southeast Asia. The main characteristics of these markets (i.e. high political uncertainty and corruption, lack of supporting institutions for earlystage investment and legal protection for minority shareholders such as BAs) affect BAs' profiles and investment practices in comparison to developed economies. More specifically, the authors identify seven articles exploring the BAs' investment process in Vietnam (Scheela and Nguyen, 2001, 2004), Philippines (Scheela, 2006; Scheela and Isidro, 2008, 2009) and Thailand (Scheela and Jittrapanun, 2008, 2012), concluding that BAs (and VCs) in these countries, in spite of the numerous 'institutional voids', actively support the funding and development of early-stage and high-growth entrepreneurial ventures. They overcome such difficulties by adopting different investment strategies based, primarily, upon significant informal networking and co-investment activities. While BAs in developed countries typically co-invest to reduce financial risk, in emerging countries co-investing is relevant to manage high levels of financial, legal, currency, political, economic and market risks. Informal networking is extremely important because formal institutions, such as clubs and syndicates, are mostly lacking (Scheela et al., 2015).

A third research line, which we labelled gender, focuses on the access to angel capital by women (O'Gorman and Terjesen, 2006; Becker-Blease and Sohl, 2007), on the characteristics and investment preferences of women BAs (Harrison and Mason, 2007; Sohl and Hill, 2007) and on the effects of gender diversity on angel group investment behaviour (Becker-Blease and Sohl, 2011). It is found that women BAs are slightly more likely to invest in women-owned businesses, thus exhibiting a certain level of homophile, while gender does not seem to be a major issue in determining the supply of angel financing. However, women seek angel financing at lower rates than men (Becker-Blease and Sohl, 2007) and tend to invest less when they are in small minority as in angel groups (Becker-Blease and Sohl, 2011). Although this research line accounts for only five papers, it seems to have quite a high research impact in terms of citations, as it will be shown in the bibliometric analysis. Indeed, two articles (Becker-Blease and Sohl, 2007; Harrison and Mason, 2007) are included in the top 20 most cited publications in terms of citations per year (CPY).

The last research line Networks and groups is limited to two papers, which focus on the new roles played by BAs, emerging from the development of BA networks and groups. These works, which are grounded on social capital and social network theories, describe the function of 'gatekeepers ${ }^{\text {}}$ (Paul and Whittam, 2010) in investment syndicates and of 'nexus angels' (Porter and Spriggs, 2013).

\subsection{BA Market}

The second thematic area is BA market, which was one of the first topics addressed in BA research, first emerging in 1987 (Wetzel, 1987). This thematic area includes a total of 34 papers, which have been classified into three research lines. The first research line is Demand and supply of angel capital, which includes 15 articles. Four papers provide estimates of the total BA market in both the United States (Wetzel, 1987; Gaston, 1989) and the United Kingdom (Mason and Harrison, 2000, 2008), while 10 works specifically concentrate on the understanding of the micro and macro determinants of the demand and supply of angel financing. In general, findings suggest that entrepreneurial activity (i.e. demand for informal investment) generates its own supply of finance, as a result of both micro and macro factors (Burke et al., 2010; De Clercq et al., 2012, 2014). This stream of literature also analyses the impact of economic cycles (Sohl and Rosenbers, 2003; Månsson and Landström, 2006) and of the changes in the national taxation systems and governmental regulations (Månsson and Landström, 2006; Szerb et al., 2007a,b; Tingchi and Chang, 2007) on the evolution of the BA market in several countries (Freear et al., 1995; Manigart and Struyf, 1997; Veselovsky et al. 2015). Finally, one last paper (Mason and Harrison, 1997a,b) is the response to the criticisms advanced by Stevenson and Coveney (1996), who attribute inappropriate policies made by the UK government on the informal venture capital market to the influence of Mason and Harrison's misleading research. 
The second research line is Effectiveness of angel financing on regional growth, which includes six studies that investigate BAs' role in filling regional financial gaps and in stimulating regional economic development. Different studies identify in BAs (Harrison and Mason, 1991) and business angel networks (BANs) (Mason and Harrison, 1995; Aernoudt, 2004) the key to fill the new equity gap left by VCs in seed and early stage investments and stimulate entrepreneurship at the regional level. However, subsequent empirical studies are more sceptical about the role played by BAs and BANs in filling the regional equity market gap. It has been reported that in Sweden BA investments continue to be concentrated in metropolitan and university areas (Avdeitchikova, 2009), while in Scotland a major structural gap for development and expansion capital exists, which is not filled by BANs (Harrison et al., 2010a; Gregson et al., 2013). This is mainly determined by either the withdrawal of VCs from new investments (they tend to concentrate on follow-up rounds), and by BAs that have moved up in deal size, thanks to BA syndicates and co-investments with 'hybrid' financial entities (i.e. public authorities, charitable and academic sectors).

The last research line Policies to foster the informal risk capital market evaluates the effectiveness of governmental policies to support BA investing activity (13 papers). This stream of research, despite its relevant implications for entrepreneurs and policy makers, remains far underexplored and quite surprisingly not very successful in terms of citations results (see next section on bibliometric analysis). Papers in this research area are mainly concerned with the evaluation of existing governmental policies (Mason and Harrison, 1997a,b; Lerner, 1998; Mason and Harrison, 2004b; Aernoudt et al., 2007; Knyphausen-Aufse and Westphal, 2008; Collewaert et al., 2010; Christensen, 2011; Romani et al., 2013; Baldock and Mason, 2015). A few suggestions to stimulate the informal risk capital market are proposed in the literature, including policy measures to facilitate the connection between BAs and entrepreneurs, as the introduction of business introduction services and financial match-making services at a regional level (Mason and Harrison, 1992; Mason and Harrison 1993; Mason and Harrison, 1995), to stimulate syndication, promote co-investment schemes and BANs' activities, improve investors' readiness, create BAs' schools or academies (San José et al., 2005), establish corporate partnerships for new ventures and integrate different financing resources (Aernoudt, 2005).

\subsection{BA Investment Process}

The thematic area BA investment process includes a total of 68 articles (54\%). It is further divided into four research lines: selection, evaluation and funding; post-investment; impact on investees' performances and overview of the entire investment process.

\subsubsection{Selection, Evaluation and Funding}

The first research line selection, evaluation and funding is the most explored one within the thematic area BA investment process, totalling 36 papers.

This stream of literature examines the determinants of BAs' decision-making at both individual BAs and BA groups levels (Landström, 1998; Mason and Harrison, 1996b; Saetre, 2003; Sørheim, 2003; Gimmon, 2008; Harrison et al., 2010b; Brush et al., 2012; Mitteness et al., 2012b; Argerich et al., 2013; Ding et al., 2014; Rostamzadeh et al., 2014, 2015), with a specific focus on the criteria employed to reject business proposals (Maxwell et al., 2011; Carpentier and Suret, 2015a), in comparison with the decision-making criteria adopted by other types of investors, such as VCs and bankers (Haar et al., 1988; Fiet, 1995a,b; Guild and Bachher, 1996; Mason and Stark, 2004; Gimmon, 2008; Ibrahim, 2008; Fairchild, 2011; Conti et al., 2013; Hsu et al., 2014, 2015; Hellman and Thiele, 2015).

A more recent stream of literature has also focused on the decomposition of the selection stage in subsequent phases in order to analyse how the criteria applied change. It is generally found that 


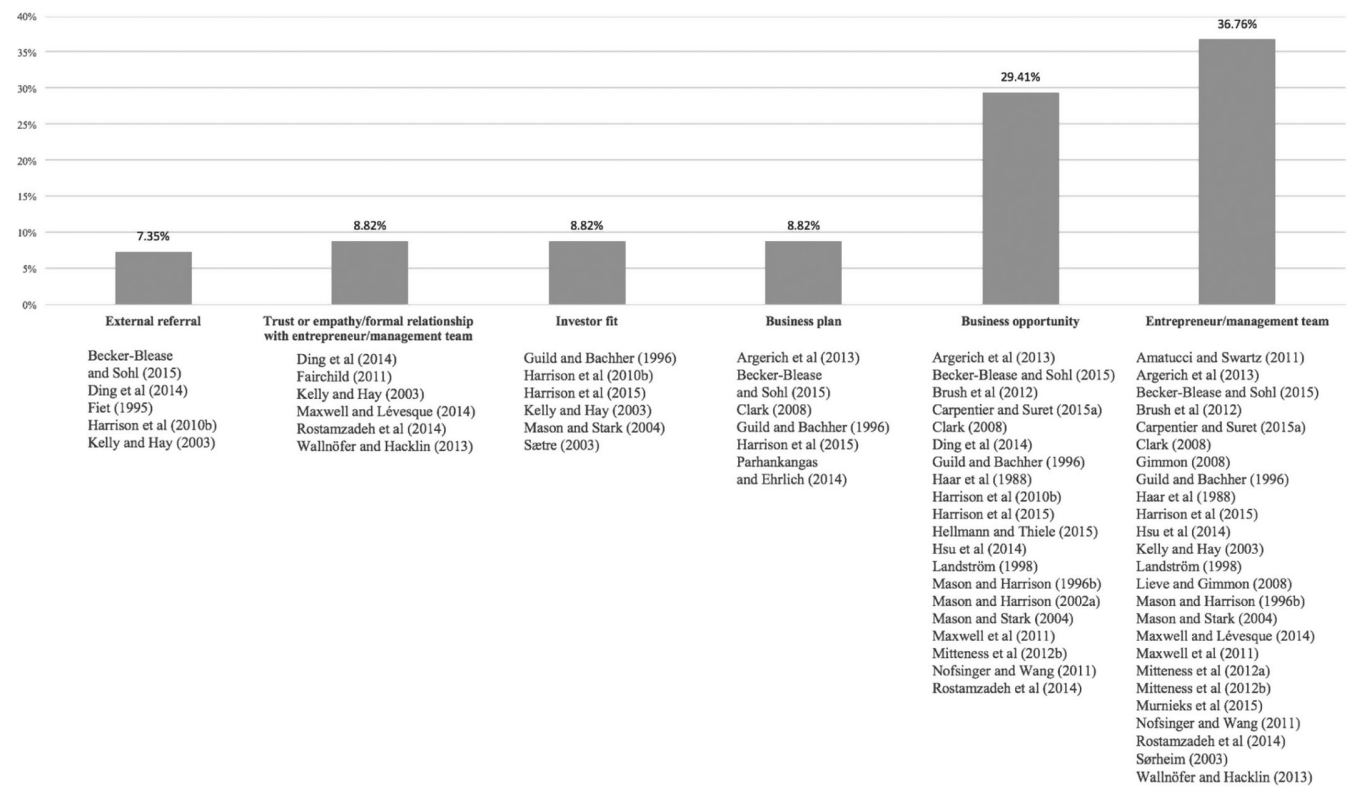

Figure 2. BA's Selection Criteria.

tangible and objective characteristics (i.e. strength of the opportunity and organizational, strategic and technological venture's readiness) are more important during the initial evaluation stage, while intangible and subjective characteristics (i.e. commitment, persuasiveness and passion expressed by the entrepreneur and the top management team) matter most in the subsequent decision stages (Maxwell et al., 2011; Brush et al., 2012; Mitteness et al. 2012b).

A significant number of works analyse to what extent the entrepreneur's soft-skill qualities affect BAs' judgements, such as the entrepreneur's personality (Becker-Blease and Sohl, 2015; Murnieks et al., 2015), his/her entrepreneurial passion (Mitteness et al., 2012a; Hsu et al., 2014), his/her presentational skills (Clark, 2008) and the trust established between the entrepreneur and the angel investors (Fairchild, 2011; Nofsinger and Wang, 2011; Wallnöfer and Hacklin, 2013; Douglas et al., 2014; Maxwell and Lévesque, 2014).

A total of three papers develop theoretical models explaining the interaction between entrepreneurs, BAs and VCs in the funding process (Fairchild, 2011; Conti et al., 2013; Hellman and Thiele, 2015). Finally, only a few papers explore the negotiation phase, focusing on how BAs' contracts affect their involvement in invested firms and investments through syndicates (Kelly and Hay, 2003), in comparison with VCs' contractual provisions (Ibrahim, 2008), and on the challenges faced by entrepreneurs in closing deals with BAs (Amatucci and Swartz, 2011; Douglas et al., 2014).

Figure 2 summarizes the main BAs' selection criteria identified in the literature. The most frequent criteria adopted by BAs in the selection process concern the human capital of the entrepreneur/management team and the business opportunity (i.e. product, market size and potential, strategy, organization) with more than $30 \%$ of the papers addressing them. BAs are found to give particular importance to the business plan (i.e. the quality of the business presentation) and to the investor fit (six papers), to the trust and empathy established between a BA and the entrepreneur/management team (five papers) and to external deal referrals, such as other investors or outside advisors (five papers). 


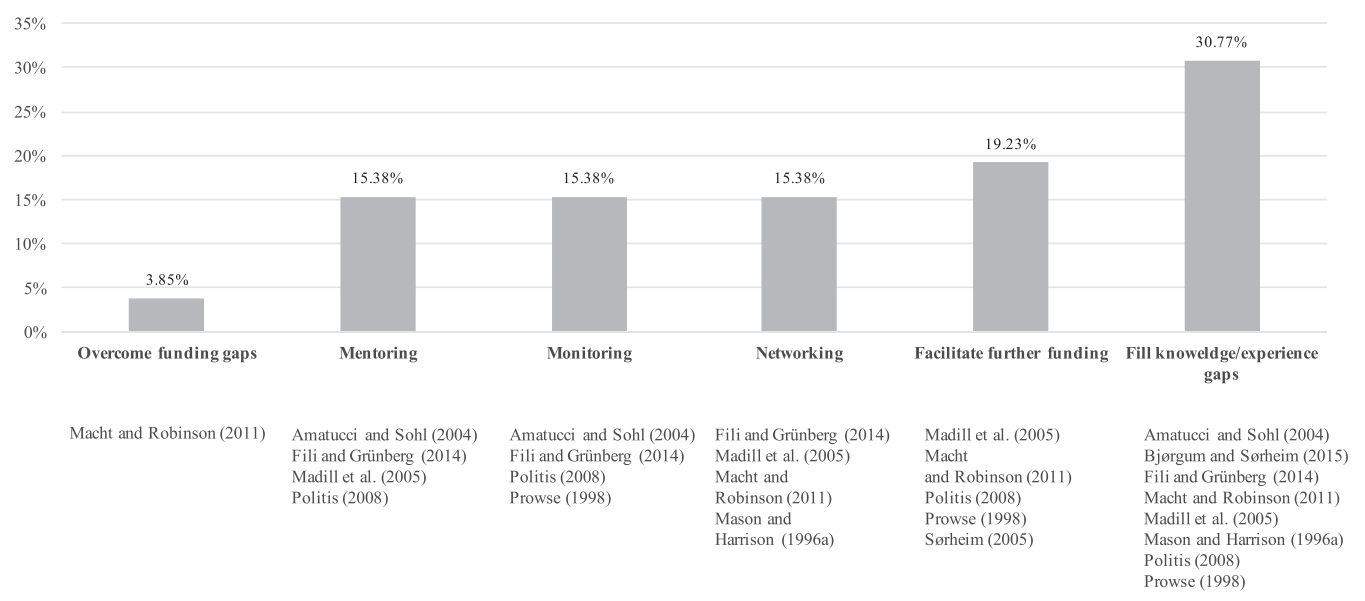

Figure 3. BA's Value-Added Activities.

\subsubsection{Post-Investment}

We identified 10 articles on the post-investment phase of the BA investment process, plus one study (Amatucci and Sohl, 2004) that we included under the research line overview of the entire investment process. Two of these studies are literature reviews (Politis, 2008; Fili and Grünberg, 2014), reporting scholarly works that examine the value-added roles served by BAs and the governance processes of BAs' post-investment involvement. ${ }^{10}$

Research on the post-investment phase is primarily based on case studies (Mason and Harrison, 1996a; Sørheim, 2005; Macht and Robinson, 2009; Macht, 2011; Fili, 2014; Bjørgum and Sørheim, 2015). Only one article by Madill et al. (2005) applies a quantitative method, finding that BAs facilitate the investee company to raise additional finance (i.e. VC), along with providing advice and mentoring, networking, assistance in everyday operations, credibility and legitimacy.

Figure 3 reports the main value-added activities performed by BAs and the papers in which they are analysed.

\subsubsection{Impact on Investees' Performances}

The research line impact on investees' performances includes 20 papers. While extant literature has extensively analysed the impact of individual BAs on both their investment returns and portfolio ventures' performances, the evidence is somehow inconclusive. Results point in the direction of BA funding being associated with enhanced venture performance, but some contrasting evidence exists. Moreover, the effects on the performance of angel groups' returns and their investee companies are still poorly examined.

At the investment level, it emerges that BAs' investment returns have a large variance and are negatively skewed, with many losses and few extraordinarily high returns (Mason and Harrison, 2002b). ${ }^{11}$ BAs typically have a relatively short holding period (four years) and trade sale is the most common exit strategy, which is preferred over IPO exit by angel groups too (Roach, 2010; Capizzi, 2015; Carpentier and Suret, 2015b), although angel-backed companies achieve the best performances through IPOs (Mason and Harrison, 2002b).

A few studies question whether formal VC methodologies can be successfully transferred to BAs (Wiltbank, 2005; Wiltbank et al., 2009). It is shown that investing at earlier stages of venture development 
and providing more post-investment involvement results in fewer negative exits, while doing more due diligence leads to a higher number of failures, but also to more extraordinarily returns (Wiltbank, 2005). Moreover, BAs, who emphasize the use of non-predictive mechanisms (e.g. more post-investment involvement, pursue of possible courses of action based on prior experience) over predictive control mechanisms (e.g. market research, surveys, detailed financial models) in the selection process, experience fewer negative exits (Wiltbank et al., 2009).

At the venture level, prior research has focused on IPO performance (or underpricing) as the primary measure of venture performance, finding contrasting results. A few studies report that BA financing is associated with better IPO performances or lower IPO underpricing (Chahine et al., 2007; Bruton et al., 2009; Hearn, 2014), especially in civil law countries (Bruton et al., 2010). Other studies have instead found that angel-backed IPOs do not outperform non angel-backed IPOs, and may even perform worse (Johnson and Sohl, 2012a,b). A similar positive effect on ventures' performances is found at the angel group level: companies funded by angel groups experience superior outcomes in terms of higher survival rates, successful exits, employment growth, patenting and web traffic (Kerr et al., 2014). These results demonstrate that there is ample room for researchers to further investigate BAs' exits and clarify apparently contrasting evidence.

Another stream of literature investigates the impact of trust and BA network connections on investees' performance (Bammers and Colleweart, 2012; Werth and Boeert, 2013). It is showed that BAs' trust perceptions lead to higher perceived venture performance up to a certain threshold, beyond which the positive effect is displaced (Bammers and Colleweart, 2012). Moreover, ventures backed by better connected BAs are more likely to receive subsequent funding by VCs and to successfully exit through trade sale or IPO (Werth and Boeert, 2013). Partially connected with this last stream of research, one paper (Colleweart, 2012) examines the angel investor-entrepreneur relationship in their respective exit processes and the impact of different types of conflicts on the intention of the two actors to exit.

Figure 4 shows the main investment performance measures, used in the literature. The most frequent approaches to assess BAs' investment performance are exit through IPO and internal rates of returns (IRRs) with nine papers each, followed by exit through trade sale (four papers). Venture's operating

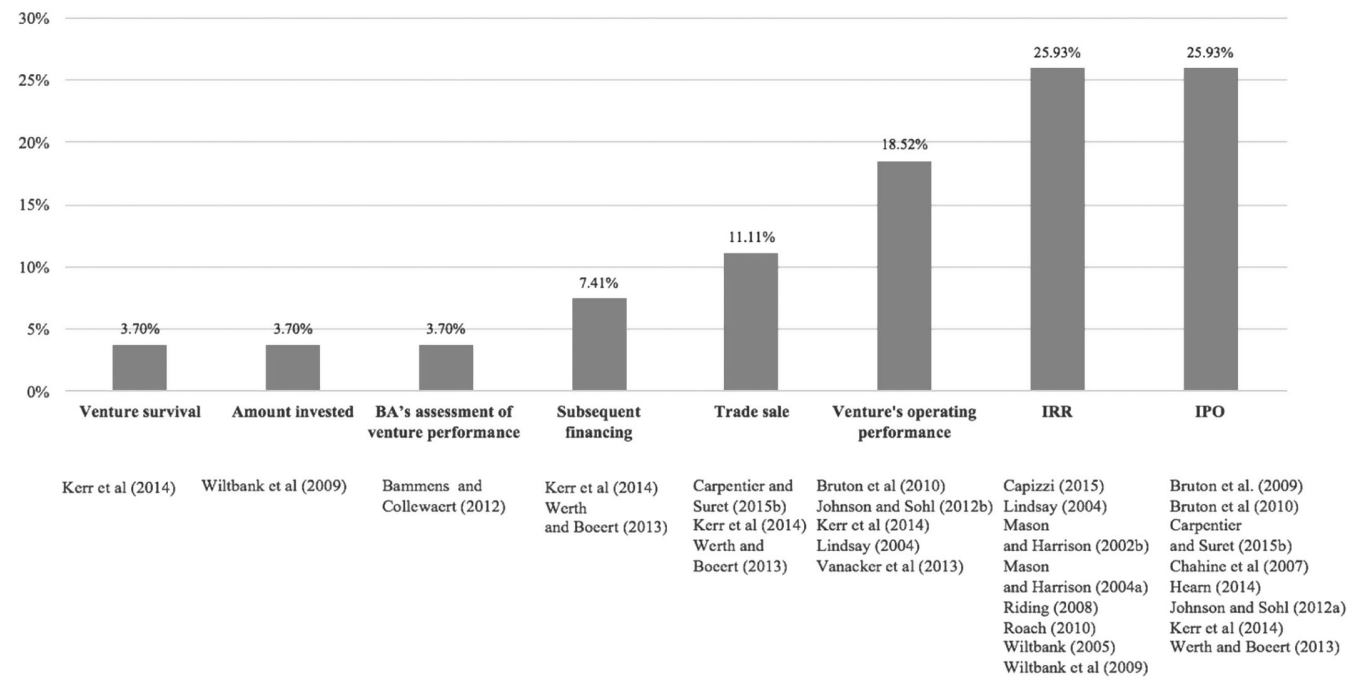

Figure 4. BA’s Investment Performance Measures. 
performance is studied only in five papers, while one paper relies on BAs' perceived evaluation of venture performance. Another potential important measure, that is subsequent financing, is almost unexplored, accounting for only two papers.

\subsubsection{Overview of the Entire Investment Process}

The last research line overview of the entire investment process includes 11 papers that analyse the entire investment process, 2 of which are literature reviews (Florin et al., 2013; Scheela et al., 2015). Out of 11 articles, 4 papers investigate the role played by different institutional settings on the BA investment process in emerging economies, such as Thailand, China, Philippines (Scheela and Isidro, 2008; 2009; Xiao and Ritchie, 2011; Scheela and Jittrapanun, 2012). Amatucci and Sohl (2004), Paul et al. (2007) and Festel and De Cleyn (2013b) provide a description of the different phases of the BA investment process, focusing, respectively, on the comparison with the VC's process, on the role of gender in the searching, negotiation and post-investment phases, and on founding angels' specific investment practices, while Elitzur and Gavious (2003) develop a theoretical model analysing the interactions between an entrepreneur, a BA and a $\mathrm{VC}$ during the investment process, pointing out that, due to a moral hazard problem, the entrepreneur and the $\mathrm{VC}$ are incentivized to free ride on the initial investment made by the BAs.

However, it seems that BAs and VCs can also play complementary roles when they co-invest in syndicated deals (Bonnet and Wirtz, 2012). BAs are more involved in the selection phase and first contact with the entrepreneur, while VCs take the lead in the deal-structuring phase. In the post-investment phase, both investors play strong complementary roles, being BAs more engaged in mentoring and VCs in monitoring through contracts and supervisory board involvement (Bonnet and Wirtz, 2012).

\section{Bibliometric Analysis}

In this section we present the results of the bibliometric analysis, which was performed using the software bibexcel $^{12}$ (Persson et al., 2009). ${ }^{13}$ The bibliometric analysis includes the analysis of backward and forward citations and the co-authorship analysis.

Table 2 reports the 42 different journals, where the reviewed articles have been published, ordered by number of articles. The Table also includes the total number of forward citations, the incidence of forward citations per article (CPA, representing the average number of citations received by all articles published in the journal and included in the review), and the journal impact factor (last available year, 2015). Following the subject areas classification by Scopus, the publication outlets for the analysed 148 articles refer mostly to Business, Management and Accounting (63.9\%), Economics, Econometrics and Finance $(23.7 \%)$, followed by other minority areas, such as Decision Science $(4.1 \%)$, Social Sciences (3.1\%), Computer Science (2.1\%), Engineering (2.1\%) and Environmental Science (1.0\%). Concerning Business, Management and Accounting the most common journals belong to the following subject areas: Strategy and Management (18.6\%), International Management (15.5\%) and Management of Technology and Innovation (12.4\%). These results seem to suggest that BA research is relevant across different fields of business management.

However, papers are quite concentrated in few journals; the main outlet is Venture Capital with 53 published articles (35.8\%), despite its relatively low CPA $(2.18 \%)$. A total of 17 articles are published in the Journal of Business Venturing (with a CPA of 6.46\%), followed by 10 articles published in Small Business Economics and Entrepreneurship and Regional Development. Both journals show a relatively high number of CPA (around 5.40\%). Journals with a lower impact factor (below 2.00), such as the Journal of Business Finance and Accounting and the Journal of Banking and Finance are also good outlets for BA research, attaining more than 5\% CPA each (corresponding at least to 40 forward citations). Moreover, 
Table 2. Number of Reviewed Articles by Publication Outlet.

\begin{tabular}{|c|c|c|c|c|}
\hline Journal & No. articles & No. citations & $\mathrm{CPA} \%$ & $\begin{array}{l}\text { Scopus impact } \\
\text { factor (2015) }\end{array}$ \\
\hline Venture Capital & 53 & 840 & 2.18 & 1.367 \\
\hline Journal of Business Venturing & 17 & 797 & 6.46 & 5.657 \\
\hline $\begin{array}{l}\text { Entrepreneurship and Regional } \\
\text { Development }\end{array}$ & 10 & 392 & 5.40 & 2.109 \\
\hline Small Business Economics & 10 & 391 & 5.39 & 2.642 \\
\hline International Small Business Journal & 5 & 164 & 4.52 & 3.058 \\
\hline Entrepreneurship: Theory and Practice & 5 & 113 & 3.11 & 4.223 \\
\hline Journal of Private Equity & 5 & 18 & 0.50 & 0.030 \\
\hline Journal of Banking and Finance & 3 & 132 & 6.06 & 1.826 \\
\hline Technovation & 3 & 58 & 2.66 & 3.074 \\
\hline Journal of Small Business Management & 3 & 46 & 2.11 & 2.495 \\
\hline Asia Pacific Journal of Management & 2 & 9 & 0.62 & 2.140 \\
\hline $\begin{array}{l}\text { Journal of Developmental } \\
\text { Entrepreneurship }\end{array}$ & 2 & 1 & 0.07 & 0.563 \\
\hline MIT Sloan Management Review & 1 & 100 & 13.78 & 1.951 \\
\hline Strategic Management Journal & 1 & 94 & 12.95 & 4.454 \\
\hline $\begin{array}{l}\text { Journal of Business Finance and } \\
\text { Accounting }\end{array}$ & 1 & 41 & 5.65 & 1.174 \\
\hline $\begin{array}{l}\text { Journal of Small Business and } \\
\text { Enterprise Development }\end{array}$ & 1 & 26 & 3.58 & 1.203 \\
\hline Review of Financial Studies & 1 & 25 & 3.44 & 3.824 \\
\hline Local Economy & 1 & 25 & 3.44 & 0.679 \\
\hline Journal of Business Research & 1 & 23 & 3.17 & 2.644 \\
\hline Vanderbilt Law Review & 1 & 19 & 2.62 & 0.966 \\
\hline $\begin{array}{l}\text { Journal of Economics and Management } \\
\text { Strategy }\end{array}$ & 1 & 15 & 2.07 & 0.948 \\
\hline Regional Studies & 1 & 13 & 1.79 & 1.939 \\
\hline Journal of Management Studies & 1 & 11 & 1.52 & 4.950 \\
\hline $\begin{array}{l}\text { International Journal of Entrepreneurial } \\
\text { Behaviour and Research }\end{array}$ & 1 & 9 & 1.24 & 1.418 \\
\hline International Business Review & 1 & 7 & 0.96 & 0.910 \\
\hline Managerial and Decision Economics & 1 & 7 & 0.96 & 0.754 \\
\hline $\begin{array}{l}\text { Technological and Economic } \\
\text { Development of Economy }\end{array}$ & 1 & 5 & 0.69 & 1.838 \\
\hline $\begin{array}{l}\text { International Journal of Technology } \\
\text { Management }\end{array}$ & 1 & 5 & 0.69 & 0.221 \\
\hline Industrial Marketing Management & 1 & 3 & 0.41 & 2.584 \\
\hline $\begin{array}{l}\text { International Journal of Entrepreneurial } \\
\text { Venturing }\end{array}$ & 1 & 3 & 0.41 & 0.485 \\
\hline $\begin{array}{l}\text { Journal of High Technology } \\
\text { Management Research }\end{array}$ & 1 & 2 & 0.28 & 1.109 \\
\hline Journal of Management & 1 & 2 & 0.28 & 6.646 \\
\hline
\end{tabular}


Table 2. Continued

\begin{tabular}{lcccc}
\hline \hline & No. articles & No. citations & CPA \% & $\begin{array}{c}\text { Scopus impact } \\
\text { factor (2015) }\end{array}$ \\
Journal & 1 & 2 & 0.28 & 0.687 \\
\hline $\begin{array}{l}\text { Journal of Multinational Financial } \\
\quad \text { Management }\end{array}$ & 1 & 2 & 0.28 & 1.050 \\
$\quad \begin{array}{l}\text { Team Performance Management } \\
\text { Service Industries Journal }\end{array}$ & 1 & 1 & 0.14 & 0.994 \\
$\quad \begin{array}{l}\text { Singapore Management Review } \\
\text { Journal of Management and }\end{array}$ & 1 & 1 & 0.14 & 0.000 \\
$\quad$ Governance & 1 & 1 & 0.14 & 1.244 \\
$\quad \begin{array}{l}\text { International Journal of Economics and } \\
\quad \text { Financial Issues }\end{array}$ & 1 & 0 & 0.00 & 0.374 \\
$\quad \begin{array}{l}\text { Journal of Entrepreneurship in } \\
\quad \text { Emerging Economies }\end{array}$ & 1 & 0 & 0.00 & 0.200 \\
$\quad \begin{array}{l}\text { Journal of Financial Economics } \\
\text { Technology Analysis and Strategic } \\
\quad \text { Management }\end{array}$ & 1 & 0 & 0.00 & 5.070 \\
$\quad \begin{array}{l}\text { International Journal of } \\
\quad \text { Entrepreneurship and Innovation }\end{array}$ & 1 & 0 & 0.00 & 1.197 \\
$\quad \begin{array}{l}\text { Total } \\
\quad\end{array}$ & 148 & 3,403 & 100.00 & 0.436 \\
\hline
\end{tabular}

International Small Business Journal and Entrepreneurship Theory and Practice with just five papers each are, as expected, potentially good outlets, given their discrete CPA above 3\%. Thus, we can conclude that the research on BAs potentially offers good publication opportunities if the right journals are targeted.

The papers included in the review have been authored by 187 different scholars. There is evidence of a growing scientific community, because almost half of the scholars (92) joined the community in the last five years and more than one-third (70) in the last three years. Authors are mainly based in North America (71 authors) and Europe (86 authors, of which around 30\% come from the United Kingdom), while a few are from Southeast Asia (19 authors) and other world areas (11 authors).

To analyse the dissemination of BA research, we provide an analysis of forward citations. Figure 5 shows the average number of forward citations per year (CPY) by thematic area, over the time period 1987-2015, considering all the articles included in the current review. CPY are calculated as the total number of forward citations received divided by the number of years of publication. We can see that the thematic area Investment Process has become a hot topic beginning from 2010, when it surpasses the cumulative CPY of the papers on BA characteristics. Papers belonging to the thematic area BA market have always received fewer citations than the other two aforementioned thematic areas (except for 2010), especially from 2011 and besides the potential relevant practical implications for policy makers and entrepreneurs.

Table 3 shows the 20 most cited articles by absolute number of forward citations and by CPY. These papers received a total of 1,492 citations, accounting for the $44 \%$ of the total number of forward citations. The bare count of total forward citations provides only partial evidence as a measure of success for scholarly publications, as inevitably favours older studies. Thus, to overcome this bias we also report the top 20 articles by CPY. Articles published after 2010 are now also taken into account.

Looking at the top 20 papers per forward citations some interesting observations can be advanced: first, forward citations are not much concentrated. On average, a paper cites 2.4 of the 20 most cited papers 


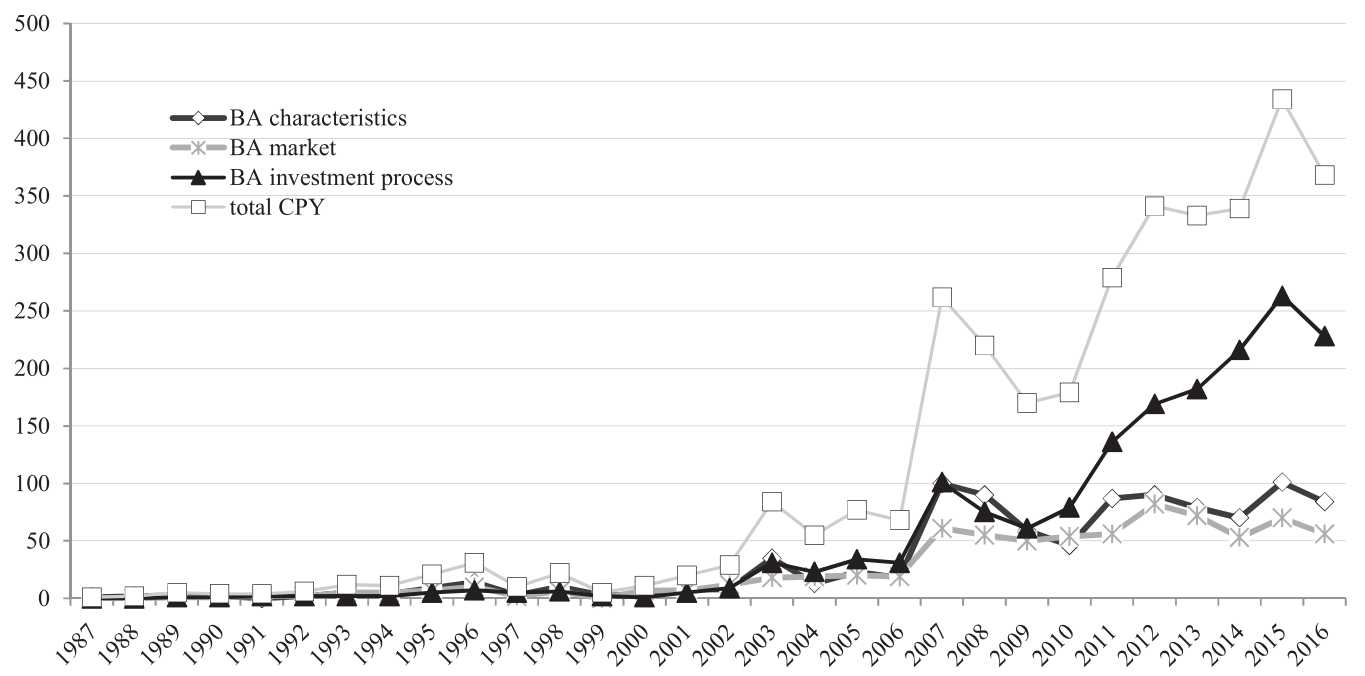

Figure 5. Average Citations per Year, by Thematic Area.

Table 3. Top 20 Most Cited Articles by Number of Forward Citations and by CPY.

\begin{tabular}{|c|c|c|c|c|c|c|}
\hline \multirow[b]{2}{*}{ Rank } & \multicolumn{3}{|c|}{ Top 20 per forward citations } & \multicolumn{3}{|l|}{ Top 20 per CPY } \\
\hline & Authors (year) & Cit. & $\mathrm{CPY}$ & Authors (year) & Cit. & CPY \\
\hline 1 & Mason and Stark (2004) & 112 & 9.3 & Bruton et al. (2010) & 94 & 15.7 \\
\hline 2 & Aernoudt (2004) & 109 & 9.1 & Kerr et al. (2014) & 25 & 12.5 \\
\hline 3 & Mason and Harrison (2002b) & 108 & 7.7 & Wiltbank et al. (2009) & 71 & 10.1 \\
\hline 4 & Wetzel and William (1983) & 100 & 3.0 & Maxwell et al. (2011) & 47 & 9.4 \\
\hline 5 & Bruton et al. (2010) & 94 & 15.7 & Mason and Stark (2004) & 112 & 9.3 \\
\hline 6 & Mason and Harrison (2002a) & 87 & 6.2 & Aernoudt (2004) & 109 & 9.1 \\
\hline 7 & Freear et al. (1994) & 75 & 3.4 & Mason and Harrison (2002b) & 108 & 7.7 \\
\hline 8 & Mason and Harrison (1996b) & 72 & 3.6 & Mitteness et al. (2012a) & 29 & 7.3 \\
\hline 9 & Wiltbank et al. (2009) & 71 & 10.1 & Becker-Blease and Sohl (2007) & 60 & 6.7 \\
\hline 10 & Fiet $(1995 a, b)$ & 68 & 3.2 & Mason and Harrison (2002a) & 87 & 6.2 \\
\hline 11 & Harrison and Mason (1992) & 67 & 2.8 & Bruton et al. (2009) & 40 & 5.7 \\
\hline 12 & Mason and Harrison (1995) & 66 & 3.1 & Conti et al. (2013) & 15 & 5.0 \\
\hline 13 & Landstrom (1993) & 64 & 2.8 & Collewaert (2012) & 19 & 4.8 \\
\hline 14 & Prowse and (1998) & 63 & 3.5 & Harrison and Mason (2007) & 42 & 4.7 \\
\hline 15 & Becker-Blease and Sohl (2007) & 60 & 6.7 & Chahine et al. (2007) & 41 & 4.6 \\
\hline 16 & Haar et al. (1988) & 58 & 2.1 & Clark (2008) & 35 & 4.4 \\
\hline 17 & Sorheim and Landstrom (2001) & 57 & 3.8 & Madill et al. (2005) & 48 & 4.4 \\
\hline 18 & Bygrave et al. (2003) & 56 & 4.3 & Bygrave et al. (2003) & 56 & 4.3 \\
\hline 19 & Lerner (1998) & 53 & 2.9 & Politis (2008) & 34 & 4.3 \\
\hline 20 & Freear et al. (1995) & 52 & 2.5 & Fairchild (2011) & 21 & 4.2 \\
\hline
\end{tabular}


in the field. Second, almost all of the 20 most cited publications consist of empirical studies, rather than theoretical models, methods, or other related phenomena. Third, looking at the topics addressed by the most cited papers we find a confirmation that papers focusing on BA characteristics, in particular belonging to the research lines profiles and types and international differences in profiles, and BA investment process, in particular belonging to the research lines selection, evaluation and funding and impact on investees' performances, are well represented, followed by papers on BA market.

If we examine the list of the top 20 papers per CPY, a higher number of articles focusing on the investment process are now clearly accounted for. In particular, one of the most successful research lines for scholars appears to be impact on investees' performances, with the article by Kerr et al. (2014) that receives 16 citations in its first year of publication (and a total of 25 cit.). This paper, in fact, is one of the few assessing the impact of BA groups' investments on the performances of invested firms. Of note is the presence of the authors Mason and Harrison, who publish 3 out of the top 20 articles by CPY, accounting for a total of 237 citations. Another interesting new entry is the work by Fairchild (2011), who advances a theoretical model on the entrepreneur's choice between VC and BA financing, based on an original behavioural game theoretical approach. Moreover, two articles that analyse the obstacles faced by women entrepreneurs in accessing informal risk capital (Becker-Blease and Sohl, 2007) and women BA characteristics (Harrison and Mason, 2007) also received a relatively significant number of CPY, along with the literature review on BAs' post-investment value-added activities by Politis (2008).

With regard to the analysis of backward citations (references), the 148 articles count around 4,120 non-duplicated backward citations, of which 62 consist of articles included in the current review. We distinguish between internal and external backward citations. A backward citation is internal (external) if a paper cites another paper included (excluded) in this literature review. Table 4 reports the top 20 most cited articles by both internal and external references. ${ }^{14}$

Among the 20 most cited articles 12 are internal references with the top 4 ones also consisting of internal backward citations (apart from Gaston, 1989). This shows how BA literature is quite a selfreferential research field. Precisely, this set of contributions is cited in total 145 times, accounting for nearly the $23 \%$ of the total internal references. The two most cited works are two seminal papers on typical characteristics and investment preferences of informal investors in the United Kingdom, while the article in third position provides an assessment of the UK informal venture capital market from a supply side perspective, identifying the main constraints on BAs' ability to invest (Harrison and Mason, 1992). The other most important internal references, again, include articles about BA characteristics in Sweden (Landstrom, 1993) and on the comparison between the UK informal venture capital market with the more sophisticated USA one (Mason and Harrison, 2002a).

As regards external references, the most cited publications (receiving at least 20 citations) ground either on the same topics of internal citations, as BA characteristics and motivations to invest (Wetzel, 1981b; Mason and Harrison, 1994; Van Osnabrugge and Robinson, 2000), or on the VC literature, in particular on the comparison between VCs' and BAs' investment processes and risk avoidance strategies (Fiet, 1995a,b), investment evaluation criteria and funding preferences (Freear and Wetzel, 1990; Feeney et al., 1999). Thus, it emerges that BA research shares some foundation with the VC literature, while there are no apparent links with other research fields. Only if we take into consideration the most recent papers, for example the ones published in the last two years, some contaminations from other research fields are starting to emerge, such as from trust, human and social capital theories (Bammens and Collewaert, 2014; Maxwell and Lévesque, 2014; Parhankangas and Ehrlich, 2014; Ding et al., 2015). Finally, once more Mason and Harrison confirm to be the pillars of the scientific community with 6 co-authored articles among the 20 most cited ones.

In Figure 6 we show the co-authorship network, reporting clusters composed by three or more authors for the sake of clarity ( 15 couples are omitted). First, it is evident that the field is quite fragmented. Five main clusters composed by $8-10$ scholars stand out, for the rest collaborations between 3 and 4 authors are the most common ones. Second, the few larger clusters are dominated by founders of BA research, who 
Table 4. Top 20 Most Cited Publications by Number of Backward Citations.

\begin{tabular}{|c|c|c|}
\hline Authors (year) & Backward Cit. & Backward Cit. type \\
\hline Wetzel $(1983)^{\mathrm{a}}$ & 45 & Internal \\
\hline Freear et al. $(1994)^{\mathrm{a}}$ & 35 & Internal \\
\hline Harrison and Mason $(1992)^{\mathrm{a}}$ & 33 & Internal \\
\hline Landström $(1993)^{\mathrm{a}}$ & 32 & Internal \\
\hline Gaston (1989) & 32 & External (book) \\
\hline Mason and Harrison $(2002 a)^{a}$ & 31 & Internal \\
\hline Haar et al. $(1988)^{\mathrm{a}}$ & 29 & Internal \\
\hline Van Osnabrugge (2000) & 29 & External $(\text { article })^{\mathrm{b}}$ \\
\hline Van Osnabrugge and Robinson (2000) & 28 & External (book) \\
\hline Wetzel (1981a) & 28 & External (book) \\
\hline Mason and Harrison (1994) & 26 & External (book) \\
\hline Mason and Harrison $(2002 b)^{a}$ & 26 & Internal \\
\hline Feeney et al. (1999) & 25 & External (article) $)^{\mathrm{b}}$ \\
\hline Freear and Wetzel (1990) & 24 & External $(\text { article })^{\mathrm{b}}$ \\
\hline Fiet $(1995 a, b)$ & 23 & External (article) ${ }^{\mathrm{b}}$ \\
\hline Mason and Harrison $(1996 a)^{\mathrm{a}}$ & 21 & Internal \\
\hline Landström $(1998)^{\mathrm{a}}$ & 21 & Internal \\
\hline Mason and Harrison $(1996 b)^{a}$ & 21 & Internal \\
\hline Sohl and Rosenberg $(2003)^{\mathrm{a}}$ & 20 & Internal \\
\hline Wiltbank $(2005)^{\mathrm{a}}$ & 20 & Internal \\
\hline Lumme et al. (1998) & 20 & External (book) \\
\hline
\end{tabular}

${ }^{a}$ Articles included in the present literature review (i.e. internal backward citations).

${ }^{\mathrm{b}}$ External articles that are not included in the Scopus database.

are still pretty active in the community. In particular, Harrison and Mason are the most prolific researchers with 20 publications each, of which 16 co-authored, followed by Sohl (10 articles), Landström (6 articles), Aernoudt and Wetzel (5 articles), and Wright (4 articles). Third, research collaborations have largely been within the same country or region, and only few cases of collaborations between North American and European researchers exist (Bygrave et al., 2003; Farrell et al., 2008; Brush et al., 2012; Gresgson et al., Harrison et al., 2010a; 2013). Moreover, as one could expect, North America affiliated authors publish more in high-ranking journals, for example 12 articles published in Journal of Business Venturing, 2 articles published in Entrepreneurship Theory and Practice, 1 article published in Review of Financial Studies, with only few exceptions (e.g. Bruton et al., 2010, who published the only article in Strategic Management Journal or Bruton et al., 2009 and Colleweart, 2012, who published in Entrepreneurship Theory and Practice).

Finally, Table 5 illustrates the methodologies used in the reviewed studies, by thematic area. It can be noticed that the quantitative approach is the most frequent methodology used, accounting for $61 \%$ of the articles. Among them, surveys represent around $45 \%$ of all the methodological approaches, followed by research based on secondary data. Quantitative studies also receive a higher number of citations, and 8 quantitative papers rank in the top 10 list of the most-cited publications per citations per year (CPY). Qualitative research represents a modest $26 \%$ of the reviewed papers, and it is mostly based on ex post interviews. Only few studies $(2.7 \%)$ rely on real-time observational techniques (i.e. verbal protocol analysis/policy capturing), although two of them enter the top 10 list of the most-cited papers, 

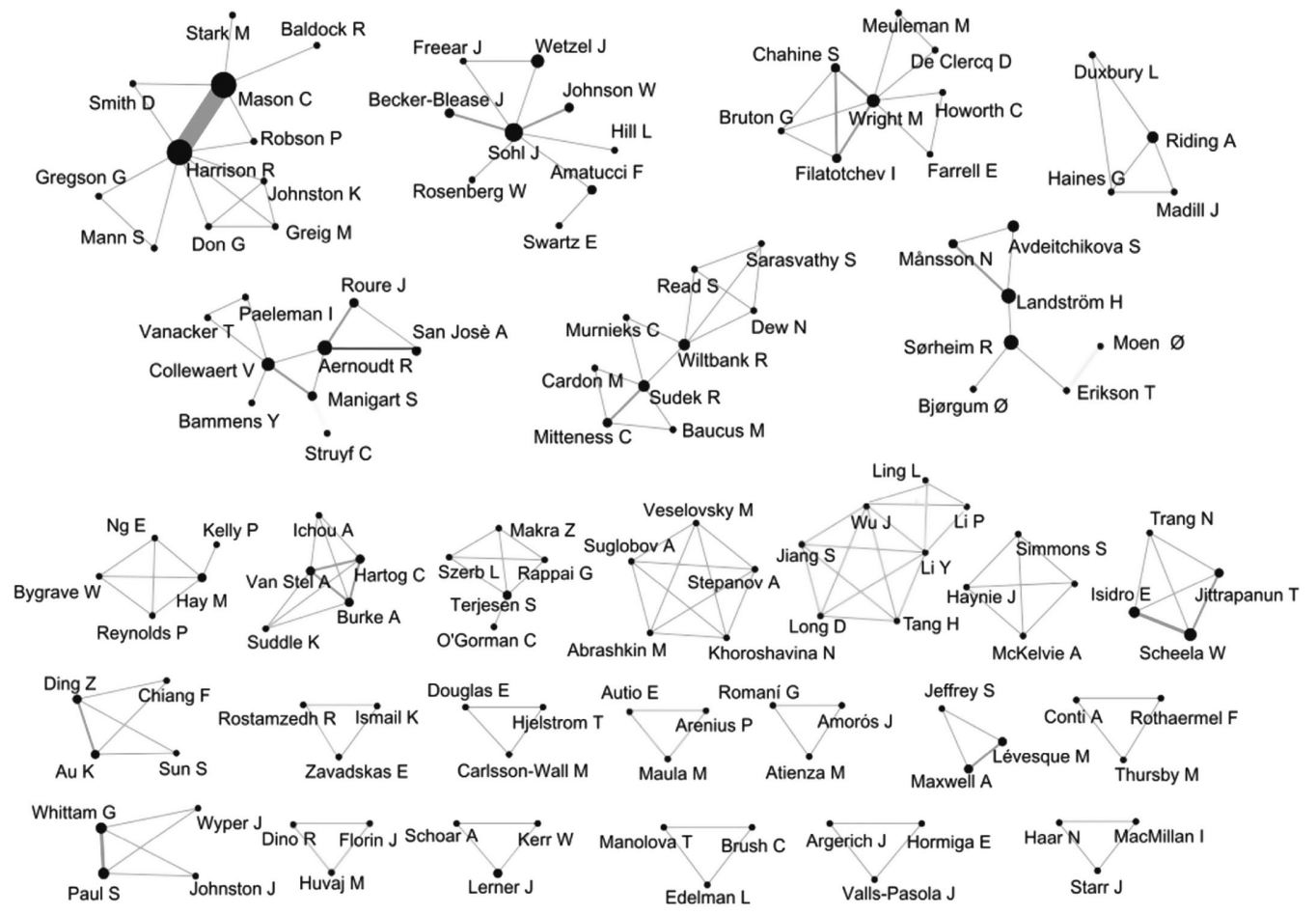

Figure 6. Co-Authorship Analysis.

Table 5. Methodological Approaches, by Thematic Area.

\begin{tabular}{lcccc}
\hline \hline & BA characteristics & BA market & $\begin{array}{c}\text { BA investment } \\
\text { process }\end{array}$ & Total \\
\hline Quantitative & $\mathbf{3 0}$ & $\mathbf{1 7}$ & $\mathbf{4 3}$ & $\mathbf{9 0}$ \\
survey & 29 & 12 & 26 & 67 \\
secondary data & 1 & 5 & 9 & 15 \\
observational studies & & & 4 & 4 \\
content analysis & & & 3 & 3 \\
experimental studies & $\mathbf{3}$ & 4 & 1 & 1 \\
Qualitative (case study) & 2 & 1 & $\mathbf{2 4}$ & $\mathbf{3 9}$ \\
ex post interviews & & $\mathbf{1 2}$ & 21 & 3 \\
observational studies & 1 & & 1 & 9 \\
secondary data & $\mathbf{1}$ & $\mathbf{4}$ & $\mathbf{1}$ & $\mathbf{3}$ \\
Mixed method & $\mathbf{1}$ & $\mathbf{4}$ & $\mathbf{5}$ \\
Literature review & $\mathbf{2}$ & $\mathbf{5}$ & $\mathbf{1 1}$ \\
Theoretical & & & & \\
\hline
\end{tabular}


demonstrating that these techniques may lead to high-quality and high-impact research. Finally, we identified 5 papers of literature review and 11 theoretical papers, 5 of which develop formal theoretical models on BA market and BA investment process.

In this respect, it is important to highlight the significant methodological obstacles of conducting BAs' research. BAs are very difficult to identify, because of their anonymous and invisible nature, which makes sampling extremely problematic. As a result, the majority of the studies rely on convenience samples (Avdeitchikova et al., 2008). Moreover, BAs are especially invisible in emerging economies compared to developed economies, as they tend to keep a low profile, avoid institutions and rely on personal connections to find investments. Typically, this results in small and non-random samples, especially in emerging countries. Some of these methodological challenges have been addressed in a special issue of Venture Capital (2008, Volume 10, no. 4) in three main papers (Avdeitchikova et al. 2008; Farrel et al., 2008; Mason and Harrison, 2008). We will further discuss these contributions in the next section, when we address the future methodological challenges of BAs' research.

\section{Conclusions and Directions for Future Research}

This paper provides a literature review of the BAs' literature from the first seminal article published in 1981-2015. As the research field matured, BA research has moved from an early emphasis on the characteristics of BAs and the informal risk capital market, towards an analysis of the BA investment process. The bibliometric analyses show that studies focusing on the analysis of the BA's investment process and, more in general, research using quantitative methods are associated with a consistent number of publications and citations per year. Despite the scientific community is quite fragmented and self-referential, the number of new authors has constantly grown over recent years, indicating that the interest on BA research has expanded and that there are good opportunities to publish high-impact articles.

In this final section, we outline the challenges that remain for future research. From a methodological point of view, the review suggests that BA research is currently using a narrow set of theories and more qualitative than quantitative tools of analysis. There is therefore significant scope to achieve a wider representation in the top journals and this could be done by a cross-fertilization of theories and concepts taken from related disciplines and by the use of new or more sophisticated quantitative methodologies, some of which are widely used in the management and sociology fields. Our review also calls for a need for more longitudinal approaches that could provide valuable insights into the temporal aspects of the BA phenomenon.

A related methodological issue that should be addressed by future research is the construction of high-quality samples of BAs, in order to avoid the exclusive reliance on convenience samples drawn from formalized angel networks or associations that could not be representative of the broad population of BAs. The use of random and multi-sample techniques are, especially, recommended to reduce sample bias, allow for longitudinal analysis (see Avdeitchikova et al. 2008; Farrell et al., 2008) and estimation of the overall BAs' market size (Mason and Harrison, 2008). Thus, a combined use of different sources to identify BAs and their investment activity is essential (e.g. BANs, angel syndicates and investment schemes providing tax incentives). Sampling from publicly available business registration data could also improve representative quality, especially in emerging countries, where angel groups and BANs are less developed (Farrel et al., 2008).

Moreover, the review has emphasised that additional research on BAs is needed in emerging economies, especially in some of the fastest-growing markets, such as India, South America or Southeast Asia, which have received very limited attention by prior literature. Indeed, for both developed and emerging economies, we need to implement representative sampling methods that allow to achieve comparable and generalizable results on BAs' characteristics, types of informal investors, BAs' investment preferences and strategies that apply broadly to the institutional context in which they are embedded. 
From a content point of view, there are many avenues for future research. We articulate the discussion of the research directions along the thematic areas and research lines previously identified.

\subsection{BA Characteristics}

\subsubsection{Profiles and Types}

Although it is the earliest topic addressed by BA research, this research line could be revitalized, especially in connection with other areas of inquiry, such as BA investment process. Researchers have primarily focused on conventional human capital characteristics (i.e. education, experience, geographical location), without in-depth assessments of more intangible aspects (i.e. physical appearance, reputation, commitment, attention to ethical values, cultural norms, passion and network ties). More studies are needed to explore to what extent these intangible human capital aspects impact on the different phases of the investment process and on distinct investment contingencies (e.g. activities performed in the invested firm, holding periods, round of entry and staging strategies). In this regard, it would be interesting to understand whether investors sharing certain soft characteristics would value opportunities differently, add value differently to invested ventures and ultimately influence the overall venture's performances.

Another interesting topic that deserves attention concerns tangible and intangible individual factors (of both investors and entrepreneurs) that shape the matching between entrepreneurs and angel investors. Is there a positive sorting in the BA market, as it happens in the VC market, so that the most reputable investors choose the best entrepreneurs and vice versa? Does the heterogeneity (or rather the homogeneity) in entrepreneurs' and investors' individual characteristics allow a better valuation of the deal, allocation of financial sources and access to finance? Which factors moderate the effects on investor-entrepreneur fit (e.g. quality of the venture, investor's resource endowment and conditions of the financial markets)? These are all questions that are likely to be at the leading edge of the academic debate in the next years and that could be addressed with finer grained data and the adoption of a wide range of methods.

\subsubsection{International Differences in Profiles}

Individual BA characteristics, as previously outlined, can impact deal evaluation, funding decisions, value adding activities and exit routes. However, BAs' profiles and types are likely to be influenced by legal, cultural, social norms and habits, which vary across countries and regions. More research is needed to assess both with-in and cross-country differences (similarities) on investors' behaviour in the light of their characteristics. In particular, the differences in BAs' profiles in emerging and developed countries have been marginally addressed so far (Li et al., 2014; Scheela et al., 2015). A further development of this research stream will allow to improve our understanding of BAs' characteristics in emerging economies, where the population of BAs is particularly invisible and where financial markets and BAs' networks are still underdeveloped. In particular, it would be interesting to understand whether BAs' profiles and investment preferences are affected by market inefficiencies and the lack of formal and effective institutions.

Therefore, we call for scholars to address questions like: Do different institutional environments shape BAs differently in their qualifying features? In particular, do BAs have distinct profiles in emerging and advanced economies? Is the matching between entrepreneurs and angel investors easier in certain geographical contexts than in others or does the 'institutional void' in emerging economies make it more difficult? Are BAs' human capital aspects (both tangible and intangible) leading to successful approaches in certain contexts but not in others? Do BAs' types adjust to varied institutional settings? More in general, what type of relationship exists between culture, institutional factors, BAs' investment patterns and outcomes and how does it vary in intensity and directions across countries at different levels of 
development? Exploring such questions would provide important insights into how the characterization of angel investors diverges within a broad range of institutional contexts.

\subsubsection{Gender}

The theme of gender has been much underexplored, even if it could potentially produce high-impact research, as indicated by two papers (Becker-Blease and Sohl, 2007; Harrison and Mason, 2007) out of the total 5 addressing this theme, which entered the top 20 most-cited list. Future studies could explore a number of interesting issues. Do women BAs have the same human capital characteristics than their men peers? For instance, are women BAs more risk tolerant than men, do they experience higher (lower) failure rates? Are these characteristics affecting their investment behaviour in the same way of men? Do women BAs have different mental constructs to evaluate deals, to take funding decisions and to manage capital and post-investment relationships? Why are women business angels underrepresented in the BA market? Is the rise of women angel groups facilitating the matching between entrepreneurs and women business angels? How is gender shaping the relationship between angels and VCs? How is gender affecting the group thinking behaviour of investors in case of groups of BAs? Each of these questions warrants further exploration.

\subsubsection{Networks and Groups}

As the BA market has matured, BAs have become more professionalized, tend to join together in semiformal or organized networks/groups and their investment process increasingly resembles that of VC funds. However, additional research is needed to improve the overall understanding of the challenges and issues faced by organized angel groups and networks. Future studies can uncover who is attracted by angel networks or groups (e.g. individuals that would have never become solo angels?), how BAs connect to domestic and international networks, how they position into the network and manage their network relationships, how they interact with other members in the investment process and the extent to which investment decisions are influenced by group thinking. Additional questions concern: What role do social capital and the positioning of investors into a network play in driving the selection of which ventures to finance? Does the heterogeneity in terms of competences, experiences, education within the group favour the investment decision? Or rather what drives most the decision making is the homogeneity of BAs? Little is also known about how syndicates operate, if they implement practices and risk reduction strategies similar to VC investors, what are the differences in terms of management and investment practices in different institutional settings. These questions represent a major opportunity for researchers in the entrepreneurial finance field.

\subsection{BA Market}

\subsubsection{Demand and Supply of Angel Capital}

Many of the studies reviewed under this research line have not provided an adequate account of the historical, cultural, economic, social or institutional factors determining the matching between demand and supply of angel capital and little scholarly attention has been devoted to the challenges to overcome to bring the two sides together. The demand and supply of BA financing is influenced by regulatory changes, tax policies, corporate governance regimes, legal environment (e.g. investor protection rights), level of development of financial markets, which greatly vary across nations and between emerging and advanced economies. In particular, the lack of institutions supporting venture financing in emerging economies is expected to hamper the demand and the supply of angel capital, even if recent research seems to suggest 
that BAs are able, somehow, to overcome these institutional challenges and provide financial resources to new entrepreneurial ventures (Scheela et al., 2015). More extensive research on these issues would further our understanding of which are the consequences for both entrepreneurs and investors of these factors in different institutional settings. Specifically, future studies on emerging markets could support or contradict these preliminary results.

Finally, another theme that has not received much consideration is the impact on the demand side of the changes that have recently taken place in the supply side, namely the organization of angels into angel groups/networks or the adoption by BAs of investment practices similar to the ones adopted by VCs.

\subsubsection{Effectiveness of Angel Financing on Regional Growth}

The geography of BAs' investment activity and the role of BAs in filling the new regional equity market gap, which is deepening at the lower end of the risk capital market, is worth further investigation by future works, for its important policy implications and potential impact on entrepreneurial activity. As prior research suggested, the regional concentration of BAs' investments puts start-ups located in outer regions at disadvantage compared to their equivalents in core economic regions (Avdeitchikova, 2009; Harrison and Mason, 1995). New studies (i.e. outside the United Kingdom) could explore the presence of geographical concentration of BA activity in other settings and to what extent this is determined by institutional, social and economic factors. Further research is needed to assess to what extent the emergence of BA networks and groups can effectively fill the regional equity gap and which legal, institutional, social, regulatory conditions allow BA financing to engage with other sources of financing (i.e. crowdfunding, VC, public sector finance).

\subsubsection{Policies to Foster the Informal Risk Capital Market}

Research on the effectiveness of governmental policies in stimulating BA activities has been limited, despite its important economic implications and benefit for entrepreneurs and BAs alike. Consequently, new studies will have to better clarify in which direction public policy measures should be pointed to stimulate BA risk capital market and to fill the regional equity gap identified in the literature. There is the need to evaluate the efficacy of the introduction of public sector measures to stimulate both the demand and supply side of the BA market, especially in peripheral regions. Are tax reliefs, public guarantees, co-investment schemes and educational initiatives enough to encourage angel investments? Can tax incentives be extended to angels investing in pooled investment vehicles? Is it more effective to sustain the development of BA networks rather than BA groups or viceversa? Which measures can be implemented to facilitate the matching between entrepreneurs and BAs, and should these measures be differently shaped for distinct types of investors and entrepreneurs?

\subsection{BA Investment Process}

\subsubsection{Overview of the Entire Investment Process}

Research on BA investment process is still underdeveloped. In general, works establishing patterns of causes and effects in the different sequential stages throughout the entire investment process are very limited. Indeed, only eight empirical papers study the overall investment process, and most of them focus on a particular geographical area or BA's typology. Therefore, we see numerous opportunities to enlarge the overview of the entire investment process, with additional insights into the diverse roles played by individual angels, networks and groups. We detail a number of potential future research lines spanning the overall investment process in the following paragraphs. 


\subsubsection{Selection, Evaluation and Funding}

Future research into the selection, valuation and funding stages should examine how investment decisions and patterns change as BAs gain experience and maturity, change their risk-return preferences or syndicate with other investors, controlling for the diversity of the institutional context in which they operate. There is a lack of empirical knowledge on whether evaluation criteria are weighted differently throughout the various stages of the investment process and if this is influenced, to some extent, by BAs' individual characteristics (both tangible and intangible). Little is known about the negotiation phase, and specifically on the determinants of deal terms and deal pricing, which are of crucial importance for both entrepreneurs and BAs, as they determine their relative control over the venture and influence BAs' returns at the exit.

It would be insightful to explore all these issues at the level of both individual angels and BA groups and networks. Indeed, only six papers among those reviewed have examined the investment decision process followed by BA groups. Hence, there is ample room for further research in expanding the number and types of angel groups sampled and in examining how investment groups differing on the size, corporate governance, level of professionalism and maturity differently balance investment criteria in their decision making process and which model likely leads to better decisions.

Finally, the relationship between BAs and VCs represents another promising direction for future research, in particular because empirical research is rather limited. How does the level of engagement of solo angels and BAs networks/groups with VCs influence the selection, evaluation and negotiation of the deals? Who is steering valuations, negotiations and contract terms? Are the inter-relationships between VCs and BAs characterized by complementarity or substitutability and how is this affecting the investment process? Do the characteristics of angels (experience, education, social capital) matter in influencing the decision of VCs to co-invest with BAs or to invest sequentially? Understanding to what extent the interaction with VCs affects the decision making process in all these stages is clearly left for future studies.

\subsubsection{Post-Investment}

The motivations and implications of value-added activities performed by BAs in the post-investment phase are mainly based on limited case studies (a part from Madill et al., 2005). Longitudinal quantitative analyses could expand the current knowledge, in order to understand when and why certain activities performed by angels are perceived as more valuable and how they vary as the post-investment relationship unfolds. More research on the role played by third parties (e.g. other investors, the entrepreneur, board members, management), by certain human capital characteristics, and by the diversity of skills and knowledge within groups on BAs' involvement in invested companies is warranted. In that sense, the use of new methodologies (e.g. dialectical techniques, verbal protocol analysis etc.) could enable a much richer understanding of the post-investment value provided by BAs, compared to self-reported, retrospective questionnaires and interviews.

\subsubsection{Impact on Investees' Performances}

Concerning this research line, there is a need for evidence that could resolve the current contrasting results on the impact of BAs' funding both at the investment and venture level. Also, the distribution of angel groups' financial returns and how syndication affects investment and venture performance are totally underexplored or inconclusive when addressed (Wiltbank, 2005). Thus, future promising research lines could address the following questions: Would ventures that had other sources of financing before the BA investment be better off without them? Would ventures perform better when investments are syndicated or when are invested by individual angels? What does the emergence of angel groups and the function 
of gatekeepers mean for companies' post-investment performance? Does angel groups provide better investment returns to their members than those obtained by individual angels? What is the impact of co-investment strategies among BAs and VCs on investees' performances? And are there any differential effects when complementary and/or substitute roles between BAs and VCs are envisaged? Moreover, the adoption of more robust methodologies and performance measures would also allow to disentangle the causal effect of BA funding from a priori selection effect of better performing ventures by BAs themselves.

\section{Notes}

1. The literature reviews by Politis (2008) and Fili and Grünberg (2014), for example, concentrate on BAs' value adding activities in the post investment phase on the basis of a limited number of papers (i.e. 14 and 29 papers respectively). Florin et al. (2013) analyse BAs' investment process by developing a conceptual framework grounded on prospect theory, without employing a rigorous methodology in the selection of the reviewed papers. Another recent review by Scheela et al. (2015) focuses on BA research carried out in Southeast Asia.

2. Given our research objectives, we preferred to perform the bibliometric analysis on a widely recognised formal database like Scopus, which adopts a rigorous and transparent methodology to catalog articles, instead of using a more comprehensive, but less accurate tool (e.g. Google Scholar).

3. We arguably assume that such research products contain less validated knowledge, although we are aware that in this way some influential contributions might be overlooked.

4. The query was first run on 02/02/2016 and re-run on 30/08/2016 to check for recent added articles.

5. As said, Scopus excludes a number of articles on the topic. We searched within the main journals included in our sample and we found at least other 35 published articles about BAs that are not reported in Scopus. We decided not to include these papers in the present review to preserve the coherence between the thematic and the bibliometric analysis.

6. Founding angels are BAs who participate in the founding of start-ups, providing pre-seed financing and operational help.

7. One of the main sources of data for these studies is the Global Entrepreneurship Monitor (GEM) survey, a global dataset covering more than 100 countries dedicated to the study of individual-level entrepreneurial behaviours.

8. The paper is formally included under the research topic 'BA investment process' as it analyses BAs' investment process in emerging economies.

9. 'Gatekeepers' manage the outside relationships, especially with entrepreneurs, and provide internal coordination. 'Nexus angels' facilitate entrepreneurs' access to hidden angel groups and support them in the attraction of angel capital.

10. Note that some of the papers analysed by the two aforementioned literature reviews are not included in the post investment category because, either they are published in journals outside the Scopus database, or they have not been attributed to the post-investment phase, as they are descriptive in nature, without having a specific and unique focus on this stage. Therefore, we classified those papers under the thematic area BA characteristics (e.g. Prowse, 1998; Wetzel, 1983; Stendler and Peters, 2003), while we included in the post-investment research line only papers whose research questions are concerned with the identification of BAs' value-added activities.

11. Mason and Harrison (2002b) is the first study that provides an analysis of the distribution of BAs' returns, securing the authors the first place among the most cited papers on BAs (see Table 4). They find that almost half of UK BAs' investments make a loss, around 10\% achieve break-even, around $20 \%$ report IRRs higher than $50 \%$, while only $10 \%$ generate IRRs higher than $100 \%$.

12. http://www8.umu.se/inforsk/Bibexcel/ 
13. A similar approach is adopted by Ghio et al. (2015) and Raasch et al. (2013).

14. Note that six of external backward citations refer to books, book chapters or conference proceedings, which are not included in the current review.

\section{References}

Aernoudt, R. (2004) Incubators: tool for entrepreneurship? Small Business Economics 23(2):127-135.

Aernoudt, R. (2005) Executive forum: seven ways to stimulate business angels' investments. Venture Capital 7(4):359-371.

Aernoudt, R., San José, A. and Roure, J. (2007) Executive forum: public support for the business angel market in Europe - a critical review. Venture Capital 9(1):71-84.

Amatucci, F.M. and Sohl, J.E. (2004) Women entrepreneurs securing business angel financing: tales from the field. Venture Capital 6(2-3):181-196.

Amatucci, F.M. and Swartz, E. (2011) Through a fractured lens: women entrepreneurs and the private equity negotiation process. Journal of Developmental Entrepreneurship 16(3):333-350.

Aram, J.D. (1989) Attitudes and behaviors of informal investors toward early-stage investments, technologybased ventures, and coinvestors. Journal of Business Venturing 4(5):333-347.

Argerich, J., Hormiga, E. and Valls-Pasola, J. (2013) Financial services support for entrepreneurial projects: key issues in the business angels investment decision process. Service Industries Journal 33(9-10):806-819.

Avdeitchikova, S. (2008) On the structure of the informal venture capital market in Sweden: developing investment roles. Venture Capital 10(1):55-85.

Avdeitchikova, S. (2009) False expectations: reconsidering the role of informal venture capital in closing the regional equity gap. Entrepreneurship and Regional Development 21(2):99-130.

Avdeitchikova, S., Landström, H. and Månsson, N. (2008) What do we mean when we talk about business angels? Some reflections on definitions and sampling. Venture Capital 10(4):371-394.

Baldock, R. and Mason, C. (2015) Establishing a new UK finance escalator for innovative SMEs: the roles of the enterprise capital funds and angel co-investment fund. Venture Capital 17(1-2):59-86.

Bammens, Y. and Collewaert, V. (2014) Trust between entrepreneurs and angel investors: exploring positive and negative implications for venture performance assessments. Journal of Management 40(7):1980-2008.

Becker-Blease, J.R. and Sohl, J.E. (2007) Do women-owned businesses have equal access to angel capital? Journal of Business Venturing 22(4):503-521.

Becker-Blease, J.R. and Sohl, J.E. (2015) New venture legitimacy: the conditions for angel investors. Small Business Economics 45(4):735-749.

Becker-Blease, J.R. and Sohl, J.E. (2011) The effect of gender diversity on angel group investment. Entrepreneurship: Theory and Practice 35(4):709-733

Bjørgum, Ø. and Sørheim, R. (2015) The funding of new technology firms in a pre-commercial industry - the role of smart capital. Technology Analysis and Strategic Management 27(3):249-266.

Bonnet, C. and Wirtz, P. (2012) Raising capital for rapid growth in young technology ventures: when business angels and venture capitalists coinvest. Venture Capital 14(2-3):91-110.

Brettel, M. (2003) Business angels in Germany: a research note. Venture Capital 5(3):251-268.

Brush, C.G., Edelman, L.F. and Manolova, T.S. (2012) Ready for funding? Entrepreneurial ventures and the pursuit of angel financing. Venture Capital 14(2-3):111-129.

Bruton, G.D., Filatotchev, I., Chahine, S. and Wright, M. (2010) Governance, ownership structure, and performance of IPO firms: the impact of different types of private equity investors and institutional environments. Strategic Management Journal 31(5):491-509.

Bruton, G.D., Chahine, S. and Filatotchev, I. (2009) Founders, private equity investors, and underpricing in entrepreneurial IPOs. Entrepreneurship: Theory and Practice 33(4):909-928.

Burke, A., Hartog, C., van Stel, A. and Suddle, K. (2010) How does entrepreneurial activity affect the supply of informal investors? Venture Capital 12(1):21-47.

Burke, A., van Stel, A., Hartog, C. and Ichou, A. (2014) What determines the level of informal venture finance investment? Market clearing forces and gender effects. Small Business Economics 42(3):467-484.

Bygrave, W.D., Hay, M., Ng, E. and Reynolds, P. (2003) Executive forum: a study of informal investing in 29 nations composing the global entrepreneurship monitor. Venture Capital 5(2):101-116. 
Capizzi, V. (2015) The returns of business angel investments and their major determinants. Venture Capital 17(4):271-298.

Carpentier, C. and Suret, J. (2015a) Angel group members' decision process and rejection criteria: a longitudinal analysis. Journal of Business Venturing 30(6):808-821.

Carpentier, C. and Suret, J. (2015b) Canadian business angel perspectives on exit: a research note. International Small Business Journal 33(5):582-593.

Chahine, S., Filatotchev, I. and Wright, M. (2007) Venture capitalists, business angels, and performance of entrepreneurial IPOs in the UK and France. Journal of Business Finance and Accounting 34(3-4):505528.

Christensen, J.L. (2011) Should government support business angel networks? The tale of Danish business angels network. Venture Capital 13(4):337-356.

Clark, C. (2008) The impact of entrepreneurs' oral 'pitch' presentation skills on business angels' initial screening investment decisions. Venture Capital 10(3):257-279.

Collewaert, V. (2012) Angel investors' and entrepreneurs' intentions to exit their ventures: a conflict perspective. Entrepreneurship: Theory and Practice 36(4):753-779.

Collewaert, V., Manigart, S. and Aernoudt, R. (2010) Assessment of government funding of business angel networks in Flanders. Regional Studies 44(1):119-130.

Conti, A., Thursby, M. and Rothaermel, F.T. (2013) Show me the right stuff: signals for high-tech startups. Journal of Economics and Management Strategy 22(2):341-364.

De Clercq, D., Meuleman, M. and Wright, M. (2012) A cross-country investigation of micro-angel investment activity: the roles of new business opportunities and institutions. International Business Review 21(2):117129.

Douglas, E.J., Carlsson-Wall, M. and Hjelström, T. (2014) Negotiating equity share and management control of the entrepreneurial new venture. Venture Capital 16(4):287-307.

Ding, Z., Au, K. and Chiang, F. (2015) Social trust and angel investors' decisions: a multilevel analysis across nations. Journal of Business Venturing 30(2):307-321.

Ding, Z., Sun, S.L. and Au, K. (2014) Angel investors' selection criteria: a comparative institutional perspective. Asia Pacific Journal of Management, 31(3), 705-731.

Duxbury, L., Haines, G. and Riding, A. (1996) A personality profile of Canadian informal investors. Journal of Small Business Management 34(2):44-55.

Elitzur, R. and Gavious, A. (2003) Contracting, signaling, and moral hazard: a model of entrepreneurs, 'angels', and venture capitalists. Journal of Business Venturing 18(6):709-725.

Erikson, T. and Sørheim, R. (2005) 'Technology angels' and other informal investors. Technovation 25(5):489496.

Fairchild, R. (2011) An entrepreneur's choice of venture capitalist or angel-financing: a behavioral gametheoretic approach. Journal of Business Venturing 26(3):359-374.

Farrell, E., Howorth, C. and Wright, M. (2008) A review of sampling and definitional issues in informal venture capital research. Venture Capital 10(4):331-353.

Feeney, L., Haines, G.H. and Riding, A.L. (1999) Private investors' investment criteria: insights from qualitative data, Venture Capital 1:121-145.

Festel, G.W. and De Cleyn, S.H. (2013a) Founding angels as an emerging subtype of the angel investment model in high-tech businesses. Venture Capital 15(3):261-282.

Festel, G. and De Cleyn, S.H. (2013b) Founding angels as an emerging investment model in high-tech areas. Journal of Private Equity 16(4):37-45.

Fiet, J. (1995a) Risk avoidance strategies in venture capital markets, Journal of Management Studies 32:551574.

Fiet, J.O. (1995b) Reliance upon informants in the venture capital industry. Journal of Business Venturing 10(3): 195-223.

Fili, A. (2014) Business angel-venture negotiation in the post-investment relationship: the use of the good cop, bad cop strategy. Venture Capital 16(4):309-325.

Fili, A. and Grünberg, J. (2014) Business angel post-investment activities: a multi-level review. Journal of Management and Governance 20(1):89-114.

Florin, J., Dino, R. and Huvaj, M.N. (2013) Research on angel investing: a multilevel framework for an emerging domain of inquiry. Venture Capital 15(1):1-27. 
Freear, J., Sohl, J.E. and Wetzel Jr., W.E. (1994) Angels and non-angels: are there differences? Journal of Business Venturing 9(2):109-123.

Freear, J., Sohlf, J.E. and Wetzel, W.E. (1995) Angels: personal investors in the venture capital market. Entrepreneurship and Regional Development, 7(1), 85-94

Freear, J. and Wetzel, W.E. (1990) Who bankrolls high-tech entrepreneurs? Journal of Business Venturing $5(2): 77-89$.

Gaston, R.J. (1989) The scale of informal capital markets. Small Business Economics 1(3):223-230.

Gaston, R.J. (1989) Finding Private Venture Capital for Young Firm: A Complete Guide. New York: Wiley.

Ghio, N., Guerini, M., Lehmann, E.E. and Rossi-Lamastra, C. (2015) The emergence of the knowledge spillover theory of entrepreneurship. Small Business Economics 44 (1):1-18.

Gimmon, E. (2008) Entrepreneurial team-starts and teamwork: taking the investors' perspective. Team Performance Management 14(7-8):327-339.

Gregson, G., Mann, S. and Harrison, R. (2013) Business angel syndication and the evolution of risk capital in a small market economy: evidence from Scotland. Managerial and Decision Economics 34(2):95-107.

Guild, P.D. and Bachher, J.S. (1996) Equity investment decisions for technology based ventures. International Journal of Technology Management 12(7-8):787-795.

Haar, N.E., Starr, J. and MacMillan, I.C. (1988) Informal risk capital investors: investment patterns on the East Coast of the U.S.A. Journal of Business Venturing, 3(1), 11-29.

Harrison, R.T. and Mason, C.M. (1992) International perspectives on the supply of informal venture capital. Journal of Business Venturing 7(6):459-475.

Harrison, R.T. and Mason, C.M. (1991) Informal investment networks: a case study from the United Kingdom. Entrepreneurship and Regional Development 3(3):269-279.

Harrison, R.T. and Mason, C.M. (2007) Does gender matter? Women business angels and the supply of entrepreneurial finance. Entrepreneurship: Theory and Practice 31(3):445-472.

Harrison, R.T., Don, G., Johnston, K.G. and Greig, M. (2010a) The early-stage risk capital market in Scotland since 2000: issues of scale, characteristics and market efficiency. Venture Capital 12(3):211-239.

Harrison, R.T., Mason, C.M. and Robson, P. (2010b) Determinants of long-distance investing by business angels in the UK. Entrepreneurship and Regional Development 22(2):113-137.

Harrison, R.T., Mason, C.M. and Smith, D. (2015) Heuristics, learning and the business angel investment decision-making process. Entrepreneurship and Regional Development 27(9-10):527-554.

Hearn, B. (2014) The impact of institutions, ownership structure, business angels, venture capital and lead managers on IPO firm underpricing across North Africa. Journal of Multinational Financial Management 24(1):19-42.

Hellmann T. and Thiele, V. (2015) Friends or foes? The interrelationship between angel and venture capital markets. Journal of Financial Economics 115(3):639-653.

Hsu, D.K., Haynie, J.M., Simmons, S.A. and McKelvie, A. (2014) What matters, matters differently: a conjoint analysis of the decision policies of angel and venture capital investors. Venture Capital 16(1):1-25.

Ibrahim, D.M. (2008) The (not so) puzzling behavior of angel investors. Vanderbilt Law Review 61(5):14031451.

Johnson, W.C. and Sohl, J. (2012a) Angels and venture capitalists in the initial public offering market. Venture Capital 14(1):27-42.

Johnson, W.C. and Sohl, J.E. (2012b) Initial public offerings and pre-IPO shareholders: angels versus venture capitalists. Journal of Developmental Entrepreneurship 17(4):1-23.

Kelly, P. and Hay, M. (2003) Business angel contracts: the influence of context. Venture Capital 5(4):287-312.

Kerr, W.R., Lerner, J. and Schoar, A. (2014) The consequences of entrepreneurial finance: evidence from angel financings. Review of Financial Studies 27(1):20-55.

Knyphausen-Aufse, D.Z. and Westphal, R. (2008) Do business angel networks deliver value to business angels? Venture Capital 10(2):149-169.

Lahti, T. (2011a) Categorization of angel investments: an explorative analysis of risk reduction strategies in Finland. Venture Capital 13(1):49-74.

Lahti, T. (2011b) Angel investing: an examination of the evolution of the Finnish market. Venture Capital 13(2):147-173.

Landström, H. (1992) The relationship between private investors and small firms: an agency theory approach. Entrepreneurship and Regional Development 4(3):199-223. 
Landström, H. (1993) Informal risk capital in Sweden and some international comparisons. Journal of Business Venturing 8(6):525-540.

Landström, H. (1998) Informal investors as entrepreneurs. Technovation 18(5):321-333.

Levie, J. and Gimmon, E. (2008) Mixed signals: why investors may misjudge first time high technology venture founders. Venture Capital 10(3):233-256.

Lerner, J. (1998) 'Angel' financing and public policy: an overview. Journal of Banking and Finance 22(68):773-783.

Li, Y., Ling, L., Wu, J. and Li, P. (2014) Who is more likely to become business angels? Evidence of business angels and potential business angels from China. Journal of Entrepreneurship in Emerging Economies $6(1): 4-20$.

Li, Y., Jiang, S., Long, D., Tang, H. and Wu, J. (2014) An exploratory study of business angels in China: a research note. Venture Capital 16(1):69-83.

Lindsay, N.J. (2004) Do business angels have an entrepreneurial orientation? Venture Capital 6(2-3):197-210.

Lumme, A., Mason, C. and Suomi, M. (1998) Informal Venture Capital: Investors, Investments and Policy in Finland. Boston: Kluwer Academic Publishers.

Macht, S.A. (2011) The role of investee company managers in business angels' involvement: empirical insights from dyadic data. Venture Capital 13(3):267-293.

Macht, S.A. and Robinson, J. (2009) Do business angels benefit their investee companies? International Journal of Entrepreneurial Behaviour and Research 15(2):187-208.

Madill, J.J., Haines Jr., G.H. and Riding, A.L. (2005) The role of angels in technology SMEs: a link to venture capital. Venture Capital 7(2):107-129.

Manigart, S. and Struyf, C. (1997) Financing high technology startups in Belgium: an explorative study. Small Business Economics 9(2):125-135.

Månsson, N. and Landström, H. (2006) Business angels in a changing economy: the case of Sweden. Venture Capital 8(4):281-301.

Mason, C. and Harrison, R. (1992) The supply of equity finance in the UK: a strategy for closing the equity gap. Entrepreneurship and Regional Development 4(4):357-380.

Mason, C. and Harrison, R. (1993) Strategies for expanding the informal venture capital market. International Small Business Journal 11(4):23-38.

Mason, C.M. and Harrison, R.T. (1994) The informal venture capital market in the UK. In A. Hughes and D.J. Storey (Ed.), Financing Small Firms (pp. 64-111). London: Routledge.

Mason, C.M. and Harrison, R.T. (1995) Closing the regional equity capital gap: the role of informal venture capital. Small Business Economics 7(2):153-172.

Mason, C.M. and Harrison, R.T. (1996a) Informal venture capital: a study of the investment process, the post-investment experience and investment performance. Entrepreneurship and Regional Development $8(2): 105-125$.

Mason, C.M. and Harrison, R.T. (1996b) Why 'business angels' say no: a case study of opportunities rejected by an informal investor syndicate. International Small Business Journal 14(2):35-51.

Mason, C.M. and Harrison, R.T. (1997a) Business angels in the UK: a response to Stevenson and Coveney. International Small Business Journal 15(2):83-90.

Mason, C.M. and Harrison, R.T. (1997b) Business angel networks and the development of the informal venture capital market in the U.K.: is there still a role for the public sector? Small Business Economics 9(2):111123.

Mason, C.M. and Harrison, R T. (2000) The size of the informal venture capital market in the United Kingdom. Small Business Economics 15(2):137-148.

Mason, C.M. and Harrison, R.T. (2002a) Barriers to investment in the informal venture capital sector. Entrepreneurship and Regional Development 14(3):271-287.

Mason, C.M. and Harrison, R.T. (2002b) Is it worth it? the rates of return from informal venture capital investments. Journal of Business Venturing 17(3):211-236.

Mason, C.M. and Harrison, R.T. (2004a) Does investing in technology-based firms involve higher risk? An exploratory study of the performance of technology and non-technology investments by business angels. Venture Capital 6(4):313-332.

Mason, C.M. and Harrison, R.T. (2004b) Improving access to early stage venture capital in regional economies: a new approach to investment readiness. Local Economy 19(2):159-173. 
Mason, C.M. and Harrison, R.T. (2008) Measuring business angel investment activity in the United Kingdom: a review of potential data sources. Venture Capital 10(4):309-330.

Mason, C.M. and Stark, M. (2004) What do investors look for in a business plan? A comparison of the investment criteria of bankers, venture capitalists and business angels. International Small Business Journal 22(3):227-248.

Maula, M., Autio, E. and Arenius, P. (2005) What drives micro-angel investments? Small Business Economics 25(5):459-475.

Maxwell, A.L. and Lévesque, M. (2014) Trustworthiness: a critical ingredient for entrepreneurs seeking investors. Entrepreneurship: Theory and Practice 38(5):1057-1080.

Maxwell, A.L., Jeffrey, S.A. and Lévesque, M. (2011) Business angel early stage decision making. Journal of Business Venturing 26(2):212-225.

Mitteness, C.R., Baucus, M.S. and Sudek, R. (2012a) Horse vs. jockey? How stage of funding process and industry experience affect the evaluations of angel investors. Venture Capital 14(4):241-267.

Mitteness, C., Sudek, R. and Cardon, M.S. (2012b) Angel investor characteristics that determine whether perceived passion leads to higher evaluations of funding potential. Journal of Business Venturing 27(5):592-606.

Moen, Ø., Sørheim, R. and Erikson, T. (2008) Born global firms and informal investors: examining investor characteristics. Journal of Small Business Management 46(4):536-549.

Murnieks, C.Y., Sudek, R. and Wiltbank, R. (2015) The role of personality in angel investing. International Journal of Entrepreneurship and Innovation 16(1):19-31.

Nofsinger, J.R. and Wang, W. (2011) Determinants of start-up firm external financing worldwide. Journal of Banking and Finance 35(9):2282-2294.

Organisation for Economic Co-operation and Development (OECD) (2011) Financing high-growth firms: the role of angel investors. OECD Publishing. Available at: http://doi.org/10.1787/9789264118782-en, (accessed on September 30, 2016).

O'Gorman, C. and Terjesen, S. (2006) Financing the Celtic tigress: venture financing and informal investment in Ireland. Venture Capital 8(1):69-88.

Parhankangas, A. and Ehrlich, M. (2014) How entrepreneurs seduce business angels: an impression management approach. Journal of Business Venturing 29(4):543-564.

Paul, S. and Whittam, G. (2010) Business angel syndicates: an exploratory study of gatekeepers. Venture Capital 12(3):241-256.

Paul, S., Whittam, G. and Johnston, J.B. (2003) The operation of the informal venture capital market in Scotland. Venture Capital 5(4):313-335.

Paul, S., Whittam, G. and Wyper, J. (2007) Towards a model of the business angel investment process. Venture Capital 9(2):107-125.

Persson, O., Danell, R. and Schneider, J.W. (2009) How to use Bibexcel for various types of bibliometric analysis. In: Celebrating Scholarly Communication Studies: A Festschrift for Olle Persson at his 60th Birthday, International society for Scientometrics and Informetrics (pp. 9-24). Umea ${ }^{\circ}$ and Sydney: Aalborg, Copenhagen.

Pittaway, L., Robertson, M., Munir, K., Denyer, D. \& Neely, A. (2004) Networking and innovation: a systematic review of the evidence. International Journal of Management Reviews 5(6):137-168

Politis, D. (2008) Business angels and value added: what do we know and where do we go? Venture Capital 10(2):127-147.

Porter, M. and Spriggs, M. (2013) Informal private equity investment networks: the role of the nexus angel. Journal of Private Equity 16(3):48-56.

Prowse, S. (1998) Angel investors and the market for angel investments. Journal of Banking and Finance 22(6-8):785-792.

Raasch, C., Lee, V., Spaeth, S. and Herstatt, C. (2013) The rise and fall of interdisciplinary research: the case of open source innovation. Research Policy 42(5):1138-1151.

Riding, A.L. (2008) Business angels and love money investors: segments of the informal market for risk capital. Venture Capital 10(4):355-369.

Roach, G. (2010) Is angel investing worth the effort? A study of keiretsu forum. Venture Capital 12(2):153166. 
Robinson, M.J. and Cottrell, T.J. (2007) Investment patterns of informal investors in the Alberta private equity market. Journal of Small Business Management 45(1):47-67.

Romaní, G., Atienza, M. and Amorós, J.E. (2013) The development of business angel networks in Latin American countries: the case of Chile. Venture Capital 15(2):95-113.

Rostamzadeh, R., Ismail, K. and Zavadskas, E.K. (2014) Multi criteria decision making for assisting business angels in investments. Technological and Economic Development of Economy 20(4):696-720.

Sætre, A.S. (2003) Entrepreneurial perspectives on informal venture capital. Venture Capital 5(1):71-94.

San José, A., Roure, J. and Aernoudt, R. (2005) Business angel academies: unleashing the potential for business angel investment. Venture Capital 7:149-165.

Scheela, W. (2006) Knowledge transfer: the development of venture capital in South East Asia. In J. Butler, A. Lockett and D. Ucbasaran (Eds.), Venture Capital and the Changing World of Entrepreneurship (pp. 75-90). Greenwich: Information Age.

Scheela, W. and Isidro, E.S. (2008) Private equity investing in the Philippines: business angel vs. venture capitalists. Journal of Private Equity 11(2):90-99.

Scheela, W. and Isidro, E.S. (2009) Business angel investing in an emerging Asian economy. Journal of Private Equity 12(4):44-56.

Scheela, W. and Jittrapanun, T. (2012) Do institutions matter for business angel investing in emerging Asian markets? Venture Capital 14(4):289-308.

Scheela, W., Isidro, E., Jittrapanun, T. and Trang, N.T.T. (2015) Formal and informal venture capital investing in emerging economies in Southeast Asia. Asia Pacific Journal of Management 32(3):597-617.

Scheela, W. and Nguyen, V.D. (2001) Doing business in Vietnam. Thunderbird International Business Review 43:669-687.

Scheela, W. and Nguyen, V.D. (2004) Venture capital in a transition economy: the case of Vietnam. Venture Capital 6:333-350.

Sohl, J.E. and Hill, L. (2007) Women business angels: insights from angel groups. Venture Capital 9(3):207-222.

Sohl, J.E. and Rosenberg, W. (2003) The private equity market in the USA: lessons from volatility. Venture Capital 5(1):29-46.

Sørheim, R. (2003) The pre-investment behaviour of business angels: a social capital approach. Venture Capital 5(4):337-364.

Sørheim, R. (2005) Business angels as facilitators for further finance: an exploratory study. Journal of Small Business and Enterprise Development 12(2):178-191.

Sørheim, R. and Landström, H. (2001) Informal investors - a categorization, with policy implications. Entrepreneurship and Regional Development 13(4):351-370.

Stedler, H.R. and Peters, H.H. (2003) Business angels in Germany: an empirical study. Venture Capital 5(3):269-276.

Stevenson, H. and Coveney, P. (1996) A survey of business angels. In R. Blackburn and P. Jennings (eds.), Small Firms: Contributions to Economic Regeneration (pp. 37-48). London: Paul Chapman Publishing.

Sullivan, M.K. and Miller, A. (1996) Segmenting the informal venture capital market: economic, hedonistic, and altruistic investors. Journal of Business Research 36(1):25-34.

Szerb, L., Terjesen, S. and Rappai, G. (2007a) Seeding new ventures-green thumbs and fertile fields: individual and environmental drivers of informal investment. Venture Capital 9(4):257-284.

Szerb, L., Rappai, G., Makra, Z. and Terjesen, S. (2007b) Informal investment in transition economies: individual characteristics and clusters. Small Business Economics 28(2-3):257-271.

Thorpe, R., Holt, R., MacPherson, A. and Pittaway, L. (2005) Using knowledge within small and medium-sized firms: a systematic review of the evidence. International Journal of Management Reviews 7(4):257-281.

Tingchi, M.L. and Chang, B.C.P. (2007) Business angel investment in the China market. Singapore Management Review 29(2):89.

Van Osnabrugge, M. (2000) A comparison of business angel and venture capitalist investment procedures: an agency theory-based analysis. Venture Capital 2:91-109.

Van Osnabrugge, M. and Robinson, R.J. (2000) Angel Investing: Matching Startup Funds with Startup Companies - The Guide for Entrepreneurs and Individual Investors. San Francisco: John Wiley \& Sons. 
Vanacker, T., Collewaert, V. and Paeleman, I. (2013) The relationship between slack resources and the performance of entrepreneurial firms: the role of venture capital and angel investors. Journal of Management Studies 50(6):1070-1096.

Veselovsky, M.Y., Suglobov, A.E., Khoroshavina, N.S., Abrashkin, M.S. and Stepanov, A.A. (2015) Business angel investment in Russia: problems and prospects. International Journal of Economics and Financial Issues 5(3S):231-237.

Wallnöfer, M. and Hacklin, F. (2013) The business model in entrepreneurial marketing: a communication perspective on business angels' opportunity interpretation. Industrial Marketing Management, 42(5), $755-764$.

Werth, J.C. and Boeert, P. (2013) Co-investment networks of business angels and the performance of their start-up investments. International Journal of Entrepreneurial Venturing 5(3):240-256.

Wetzel Jr., W.E. (1981a) Informal risk capital in New England. In K.H. Vesper (Ed.), Frontiers of Entrepreneurship Research (pp. 217-245). Wellesley, MA: Babson College.

Wetzel Jr., W.E. (1981b) Technovation and the informal investor. Technovation 1(1):15-30.

Wetzel Jr., W.E. (1983) Angels and informal risk capital. Sloan Management Review 24(4):23-34.

Wetzel Jr., W.E. (1987) The informal venture capital market: aspects of scale and market efficiency. Journal of Business Venturing 2(4):299-313.

Wilson, H.I.M. (1995) Are the business angels of today the venture capitalists of yesterday? Journal of High Technology Management Research 6(1):145-156.

Wiltbank, R. (2005) Investment practices and outcomes of informal venture investors. Venture Capital 7(4):343357.

Wiltbank, R., Read, S., Dew, N. and Sarasvathy, S.D. (2009) Prediction and control under uncertainty: outcomes in angel investing. Journal of Business Venturing 24(2):116-133.

Wong, P.K. and Ho, Y.P. (2007) Characteristics and determinants of informal investment in Singapore. Venture Capital 9(1):43-70.

Xiao, L. and Ritchie, B. (2011) Informal investor investing and networks in China: an exploratory study. Journal of Private Equity 14(3):72-85. 